\title{
Trace elements and lead isotopic composition of copper deposits from the eastern part of the Internal Zone of the Betic Cordillera (SE Iberia): application to provenance of archaeological materials
} https://doi.org/10.1007/s41513-019-00111-

\begin{abstract}
Authors
M.Murillo-Barrosoํ, I. Montero-Ruiz², J. M. Nieto ${ }^{3}$, M. D. Camalich Massieu4, D. Martín Socas ${ }^{4}$, M. MartinónTorres $^{6}$

${ }_{1}$ Departamento de Prehistoria y Arqueología, Universidad de Granada, Campus Universitario de Cartuja, 18071 Granada, Spain, E: murillobarroso@ugr.es

2 Instituto de Historia, CSIC, C/Albasanz, 26-28, 28037 Madrid, Spain, E: ignacio.montero@cchs.csic.es

${ }^{3}$ Departamento de Ciencias de la Tierra, Universidad de Huelva, Campus de El Carmen, 21071 Huelva, Spain, E: jmnieto@uhu.es

${ }^{4}$ Departamento de Geografía e Historia, Área de Prehistoria, Universidad de La Laguna, Aptdo. 456, 38200 La Laguna, Spain, E: dmassieu@ull.edu.es, dsocas@ull.edu.es

${ }^{5}$ Department of Archaeology, University of Cambridge, Downing Street, Cambridge CB2 3DZ, UK, E: m.martinon-torres@arch.cam.ac.uk
\end{abstract}

\section{Abstract}

This paper presents trace element compositions and lead isotope analyses by MC-ICP-MS of 34 copper ore samples from the Internal Zone of the Betic Range, Southeast Spain. Samples were collected during a fieldwork campaign in the mines of Cerro Minado, Pinar de Bédar, Sierra Cabrera and Sierra Almagrera/Herrerías. Most samples are copper oxide minerals from the near surface alteration of the sulfide ore deposits. The aim of the study is to supplement the existing reference data bank on lead isotopic compositions of ancient copper mines from the Iberian Peninsula, complementing this data with trace element compositions. The latter can be useful for discriminating when isotopic overlaps occur. This characterisation will be of great usefulness for provenancing further archaeological materials. Lead isotope ratios range from 18.603 to $20.327\left({ }^{206} \mathrm{~Pb} /{ }^{204} \mathrm{~Pb}\right)$; from 15.685 to $15.779\left({ }^{207} \mathrm{~Pb} /{ }^{204} \mathrm{~Pb}\right)$ and from 38.728 to 39.702 $\left({ }^{208} \mathrm{~Pb} /{ }^{204} \mathrm{~Pb}\right)$. Data from the literature analysed by TIMS have been also considered for comparison although the larger analytical error is highlighted, especially for isotope ${ }^{204} \mathrm{~Pb}$. The lead isotopic signature of the analysed samples shows three separate isotopic fields. These fields are also consistent with differences in compositions evidenced by principal component analyses. 
Journal of Iberian Geology, 2019, pp 1-24

\section{Keywords}

Lead isotopes, Mass spectrometry, Spain, Betic Range, Copper ores, Archaeometry

\section{Resumen}

En este artículo se presentan análisis de composición de elementos traza y de isótopos de plomo por MC-ICP-MS de 34 muestras minerales de cobre de la Zona Interna de la Cordillera Bética, sureste de España. Las muestras se recogieron durante una campaña de prospección geológicominera en las minas de Cerro Minado, Pinar de Bédar, Sierra Cabrera y Sierra Almagrera/Herrerías. La mayoría de las muestras minerales son óxidos de cobre de las alteraciones superficiales de los depósitos de sulfuros. El objetivo del estudio es complementar los datos de referencia existentes de isotópos de plomo de las mineralizaciones de cobre de la Península lbérica, completando estos datos con análisis de composición de elementos traza. Esto último puede ser útil para la discriminación en caso de darse solapamientos isotópicos. Esta caracterización será de gran utilidad para la determinación de procedencia de materiales arqueológicos. Los rangos de isótopos de plomo van de18.603 a $20.327\left({ }^{206} \mathrm{~Pb} /{ }^{204} \mathrm{~Pb}\right)$; de 15.685 a $15.779\left({ }^{207} \mathrm{~Pb} /{ }^{204} \mathrm{~Pb}\right)$ y de $38.728 \mathrm{a} 39.702\left({ }^{208} \mathrm{~Pb} /{ }^{204} \mathrm{~Pb}\right)$. Los análisis antiguos realizados por TIMS y recogidos de la literatura también se han considerado para su comparación, aunque se destaca el mayor error analítico, especialmente para el isótopo ${ }^{204} \mathrm{~Pb}$. La signatura isotópica de las muestras analizadas permite la identificación de tres campos isotópicos separados. Estos campos también son consistentes con las diferencias en los patrones de elementos traza que muestra el análisis de componentes principales.

\section{Palabras clave}

Isótopos de plomo, Espectromtría de Masas, España, Cordillera Bética, Minerales de cobre, Arqueometría 


\section{Introduction}

Mining and metal production have been recurrent activities in the Iberian Peninsula from the third millennium BCE. Archaeological finds including remains of ore, slag, crucibles and other elements of the metalworking process are considerable (for overviews see Delibes de Castro and Montero Ruiz 1999; Rovira and Montero 2003). However, the corresponding studies do not always include a detailed investigation of the metal-bearing mineral resources of the surrounding area.

This article will concentrate on the copper deposits in the area surrounding the Vera basin in the Internal Zone of the Betic Cordillera. This area is chosen because of the concentration, in a limited space, of at least three chalcolithic sites, separated by less than $30 \mathrm{~km}$ as the crow flies, which have the complete production chain associated with the exploitation of copper: from mining hammers, ore remains, crucibles and slag, to drops of metal and complete objects. These sites are the settlements of Santa Bárbara in Sierra de Almagro (Camalich Massieu and Martín Socas 1999; González Quintero et al. 2018), Las Pilas in the foothills of Sierra Cabrera (Camalich Massieu and Martín Socas 1999; Murillo-Barroso et al. 2017) and Almizaraque next to the mines of Herrerías in Sierra Almagrera (Delibes de Castro et al. 1991) as well as other archaeological sites with some evidence of metallurgical works such as Campos and Zájara. The earliest evidence of metallurgy in Iberia is also proposed in this area the site of Cerro Virtud (Ruiz Taboada and Montero Ruiz 1999). These three mountain ranges show a high rate of occurrence of copper ores with distinct orogeneses (Fig.1).

With the aim of making available a more thorough geological characterisation of the copper resources available to these metalworking communities, and to facilitate provenance studies, sampling of the mining geology of the area was carried out for lead isotope and trace element analysis.

Lead isotope analysis, a technique widely used in geology, is generally employed in archaeology for the determination of the provenance of the mineral resources used by ancient metalworkers (e.g. Stos-Gale et al. 1995; Pernicka 2014). This technique, not free of problems of interpretation, has come to replace attempts to determine the source of metal objects from their chemical composition (e.g. Junghans et al. 1960, 1968, 1974). Isotopic ratios, in contrast to trace elements proportions, are not altered by the process of metal production; they can therefore be used as a fingerprint of the original deposit. However in order to establish correlations between metallic archaeological remains and geological mineral resources, not only studies of archaeological 
objects are necessary, but also an exhaustive geological characterisation of the mineral resources of the surrounding area. Given that the isotopic ratios are tightly linked to the geological age and to the metallogenic processes in the formation of each mineral deposit, and that for each deposit these ratios vary within certain ranges, it is common to find overlaps in the characteristic isotopic fields of mineral deposits of a similar age and with similar geological contexts. For the purpose of differentiating one mineral deposit from another to the greatest extent possible, these isotopic analyses are combined with the study of the trace elements present in the copper ore samples. We hope thus to contribute to a better characterisation of the finds of copper-bearing minerals in the south-east of the Iberian Peninsula, so that this will serve as a basis for later studies of the provenance of prehistoric metals recovered in the region.

\section{Geological background}

The study area is located in the eastern part of the Internal Zone of the Betic Cordillera (Fig. 2). Excluding the Neogene sedimentary cover, this region is formed by two main lithologic groups: Paleozoic and Mesozoic metasedimentary rocks of the Betic-Alpine orogen, and Miocene igneous rocks of the Almería-Cartagena volcanic belt (Arribas and Tosdal 1994). This area is structured in four geological complexes: Veleta, Mulhacén, Alpujárride and Maláguide (IGME 2001), although the latter has been largely removed by erosion in the studied area.

The Mulhacén Complex, together with the Veleta Complex, represents the metamorphic core of the Internal Zones of the Betic Cordillera and contains the oldest rocks in the region (Fig. 3). It emerges through the materials of the Alpujárride Complex. The lower section of the Mulhacén Complex is composed of Paleozoic graphite-bearing mica schists and quartzites. Its upper section rocks are Paleozoic and Permian to Triassic mica schists, calcareous schists, quartzites, marbles and igneous rocks highly deformed (Arribas and Tosdal 1994; Puga et al. 2002).

The Alpujárride structurally rests on the previous complex. Its lower section is mainly formed by Paleozoic graphite-bearing mica schists and quartzites while its upper section is largely composed of Permian and Lower Triassic phyllites as well as of Middle to Upper Triasic limestones and dolostones (Arribas and Tosdal 1994).

The mining districts sampled in this study have been: (1) Pinar de Bédar (Sierra de los Filabres) in the Mulhacén Complex; (2) Lower Sierra Cabrera in the Alpujárride Complex; (3) Herrerías 
(Sierra Almagrera), also at the Alpujárride Complex but with a hydrothermal mineralisation; and (4) Cerro Minado (Sierra de Almagro) in the Alpujárride Complex (Fig. 4).

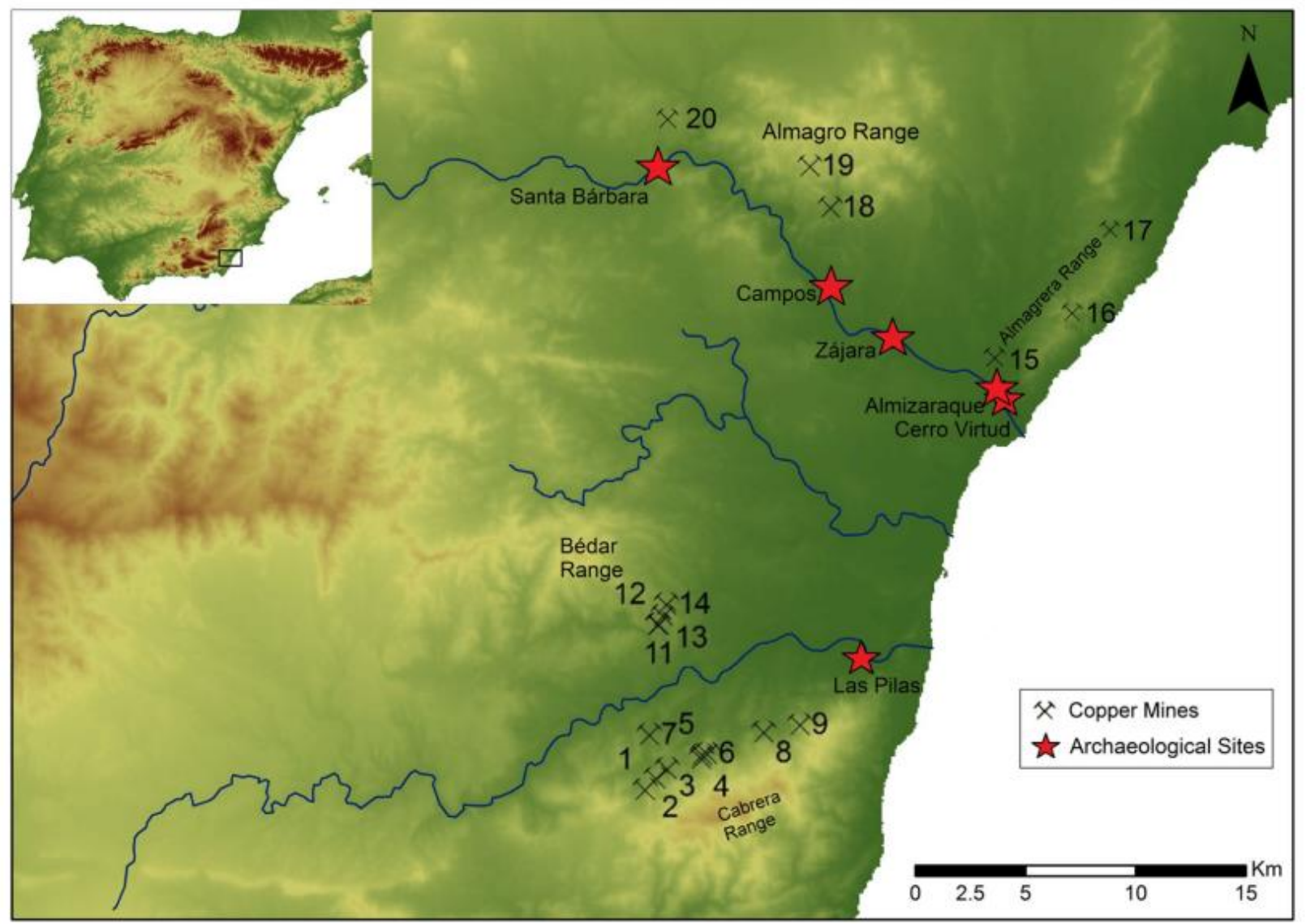

Fig. 1 Area of study showing archaeological sites with archaeometallurgical remains (red stars) and surrounding copper mines: 1, Camino Puerto Tabala; 2, Mina Indiana; 3, Cortijo Huerta Llana; 4, Cota 372; 5, Loma del Colorado 4; 6, Loma del Colorado 2 and 3; 7, Barranco del Aguador; 8, Sierra Cabrera 1; 9 , Cortijo Cantón; 10, Cabezo de los Hilos; 11, Pinar de Bédar 1 and 2; 12, Pinar de Bédar 4; 13, Pinar de Bédar 3; 14, Mina de Los Pinares; 15, Herrerías; 16, Sierra Alma-grera 1; 17, Barranco de la Cuevecica; 18, Mina los Tres Pacos; 19, Cortijo de los Guardas; 20, Cerro Minado

\subsection{Pinar de Bédar (Sierra de los Filabres)}

The mines of Bédar are found in the Easternmost section of the Sierra de los Filabrides. They were intensely worked in the nineteenth and twentieth centuries as sources of iron and lead ores (Soler Jódar 2014). It is in the most south-easterly zone close to Los Gallardos, known as the Sierra de Alcornia, where copper mines exploited from at least the sixteenth century, according to historical documentary sources have been found (Montero Ruiz 1994; Soler Jódar and Hansen 2016). This formation belongs almost entirely to the Mulhacén Complex. Lithologically, it is 
composed by an alternation of mica schists with garnet (sometimes rich in graphite) and quartzites. It starts on a Paleozoic base (calcite marbles, mica schists, quartzites, metagranite and gneiss with tourmaline), with a Permo-Triassic covering, composed of carbonate rocks (calcite and dolomite marbles), quartzites and mica schists. Gneiss with tourmaline appear in the upper tectonic units, with abundance of white feldespar and quartz (IGME 1975). Ore deposits in this location are mainly associated to marbles, are stratiform, and shows a mineral association of galena-chalcopyrite-malachite-azurite (Montero Ruiz 1994). In addition the presence of cerussite, zincolivenite, olivenite, barite and smithsonite has been documented in smaller quantities.

The high levels of zinc, arsenic and lead shown in previous X-ray fluorescence (XRF) ore analysis (Montero Ruiz 1994), and which are compatible with the composition of the mineral samples documented at the nearby archaeological site of Las Pilas (Murillo-Barroso et al. 2017), lead us to consider these deposits as a possible source of copper during Late Prehistory. During prospection for this investigation no indications of prehistoric works were documented. However intensive mining exploitation during the nineteenth and twentieth centuries could have eliminated such evidence. In the present, the housing development executed on this terrain between 2006 and 2008 has destroyed or covered the majority of the copper mines and altered the conditions for future investigation.

In addition to the semi-quantitative analyses by XRF, we had lead isotope analyses for five samples (Stos-Gale et al. 1999; Montero Ruiz and Murillo-Barroso 2010). In this survey, further ten samples were selected for lead isotope analysis and for elemental composition analysis by Inductively Coupled Plasma-Mass Spectrometry (ICP-MS).

\subsection{Sierra Cabrera}

Located in the extreme south of the Vera depression, this chain constitutes the continuation of the Sierra Alhamilla towards the east, and separates the basin of the Aguas River to the north from that of the Carboneras River to the south. The highest point is the peak of Mezquita at 960 $\mathrm{m}$, less than $10 \mathrm{~km}$ from the sea, which gives an idea of how abrupt and steep the area is, heavily affected by processes of erosion.

The greater part of the terrain is occupied by Paleozoic materials and by Permo-Triassic materials which surround the former. The Alpujarride Complex emerges in a band at the foot of the northern slopes of the range, and is followed by the Mulhacén Complex towards the south. From the 
Triassic there is a carbonate formation composed of black and greyish-brown rocks with very dense stratification and with a few interspersions of blue phyllite layers. Alternating layers of gypsum and carbonate rocks (yellowish or brown marbles, gypsum-rich marbles, clay, shale) crossed by calcite veins can also occur (IGME 1983). This phyllite formation, so striking because of its distinctive colouring, is considered to be from the Permo-Triassic, and according to Carulla (1987) belongs specifically to the Werfenian. It is here that small outcrops of copper ores are found (Fig. 5). Lastly come the oldest Paleozoic materials, consisting of schistose rocks of quartzbased and micaceous composition, with all the intermediate stages between quartzites and mica schists present. The micaceous rocks show a very developed exfoliation, and are crossed by many discontinuous veins of white quartz, the majority subparallel to the planes of the schist. In this highly folded formation a high content of iron oxides is both common and characteristic.

From Sierra Cabrera four samples of copper carbonates, taken from the phyllites of the Alpujárride Complex were selected for trace element and lead isotope analysis. These results are complemented by the seven copper ore samples already published in the literature (Available in the Oxford Archaeological Lead Isotope Database, OXALID).

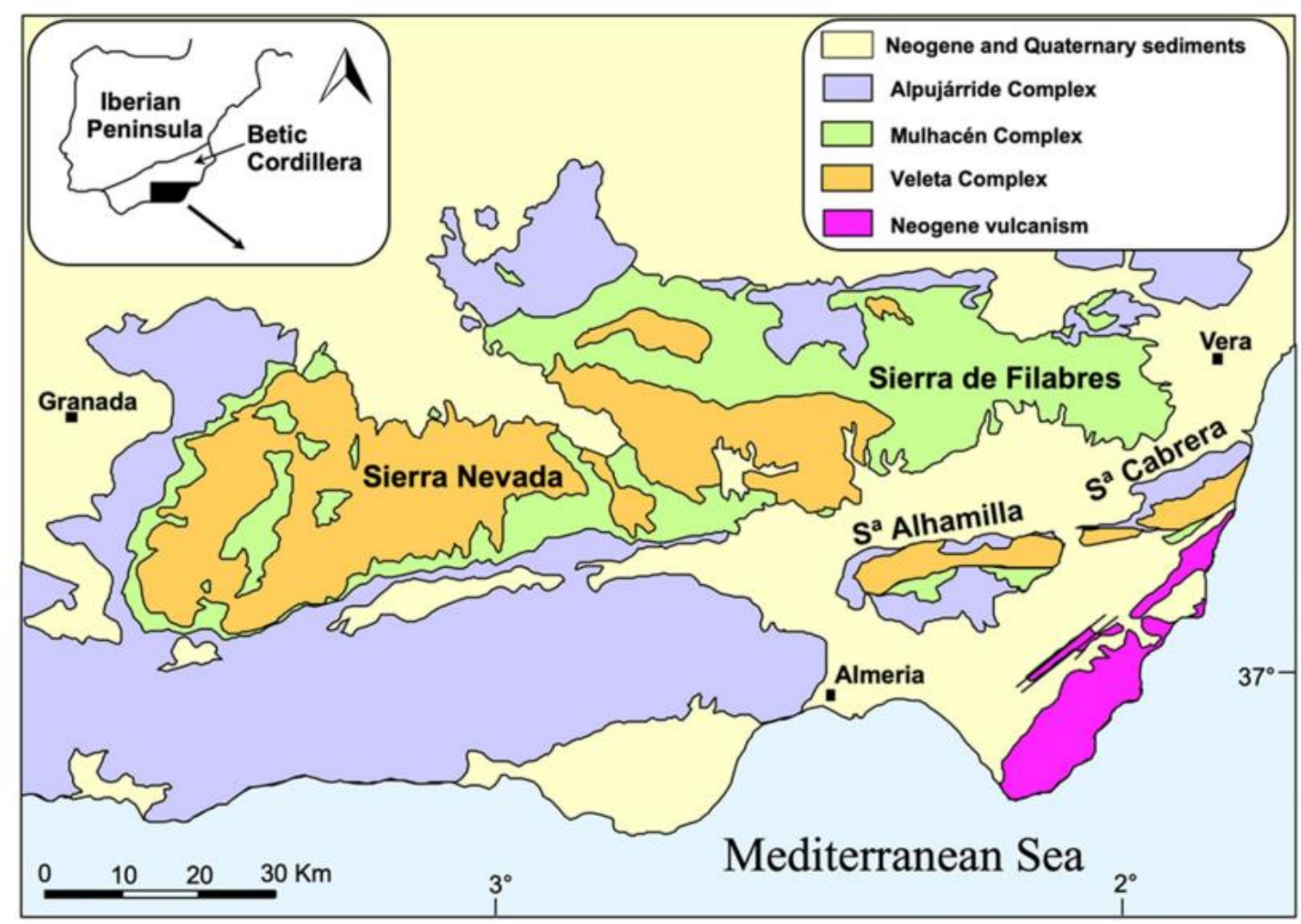

Fig. 2 Geological sketch map of the central-eastern sector of the Betic Cordilleras, showing the relationships between the Veleta, Mulhacén and Alpujárride metamorphic complexes (modified from Puga et al. 2002) 


\subsection{Herrerías-Sierra Almagrera}

Sierra Almagrera, adjacent to Herrerías, is geologically uniform. It is mainly composed by materials of the Paleozoic bedrocks of the Alpujárride Complex. The mineralization is rich in galena, silver and copper sulphides with a host rock of graphite, phyllite and quartzite. Chalcopyrite is documented in the mine Ramo de Flores. Arsenic is not detected in copper ores analysed from Sierra Almagrera although lead is usually associated to copper minerals (e.g. La Estrella Mine, Montero Ruiz 1994; Obón 2017). In the Jaroso Ravine native copper has been documented alongside malachite and azurite (Revista Minera 1850; Pellico 1852).

The Herrerías hill is found in the east of the province of Almería. It shows stepped relief with the highest point at Cerro Virtud (67 $\mathrm{m}$ above sea-level) to the south of the town of Las Herrerías (Cuevas de Almanzora, Almería). However, the hill has been flattened and the 67-m peak no longer exists. The apex has shifted to a different point due to the mining undertaken since 1993 for the extraction of barite. Here, we have a deposit of oxides and hydroxides of Fe-Mn, sulphides of base metals, and native silver, adjacent to the seams of sulphites and sulphosalts of $\mathrm{Pb}-\mathrm{Sb}$ $\mathrm{Ag}$ in the Sierra Almagrera and which constitutes a very well defined mineral zone inside the VeraGarrucha basin (Martínez Frías 1991; López Gutiérrez et al. 1993) where copper ores have also been identified.

The basin of Herrerías is delimited to the south by the Almanzora River and to the east and west by the two principal faults of the Palomares shear corridor. The eastern fault (NNE) separates it from the phyllites and Triassic graphitic schists of the Sierra Almagrera, and the western fault, practically parallel to the former, separates it from the rest of the Vera-Garrucha depression (Fig. 4). To the NW and SW of the main ore deposit appear volcanic materials dated to $7.6 \pm 0.3$ million years (Nobel et al. 1981, cf. López Gutiérrez et al. 1993). In addition to these two faults, the main outcrops are affected by other inverse faults superimposed between the two fractures of the Palomares corridor (López Gutiérrez et al. 1993).

The deposit shows simple paragenesis of oxides and hydroxides of Fe-Mn, barite, jasperoids, siderite, native silver, galena, sphalerite, pyrite, chalcopyrite, gypsum and chalcedony. In the principal outcrop at Cerro Virtud, vertically we can distinguish a zone of oxides and hydroxides, a second zone of sulphates (principally barite), and a third zone of jasperoids (López Gutiérrez et 
al. 1993). Iron appears as impregnations and metre-sized encrustations associated with native silver in sponge form, which is associated also with barite in the form of dendritic crystals

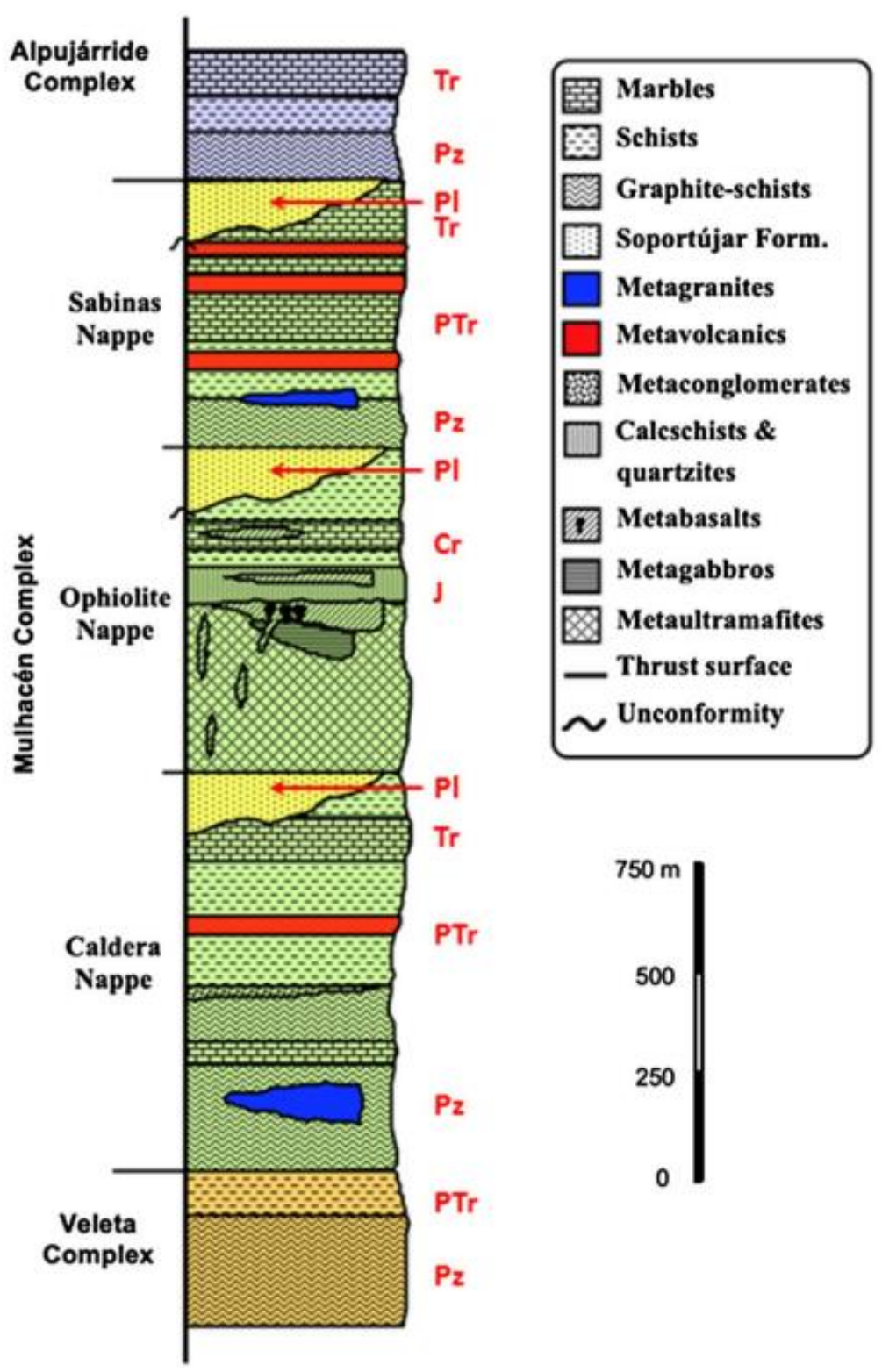

Fig. 3 Simplified lithostratigraphic column showing the main rock types of the different tectonic units and formations making up the Mulhacén Complex, together with the lithostratigraphy (not to scale) of the Veleta and Alpujárride Complexes (modified from Puga et al. 2002). Age code (labels in red): Pz Palaeozoic, PTr Permian-Triassic, $T$ Triassic, J Jurassic, $\mathrm{Cr}$ Cretaceous, PI Paleocene

(Martínez Frías et al. 1989). In the mine Nuestra Señora del Milagro de Guadalupe in Herrerías dendritic nuggets of native copper of up to $10 \mathrm{~cm}$ were found, and in the Berja mine in Herrerías 
(in the old Atrevida concession) native silver is abundant and dendritic nuggets of native copper were also found.

Both Herrerías and Sierra Almagrera, a dike type deposit, are considered epigenetic, with a similar temperature of ore deposition $\left(200-300^{\circ} \mathrm{C}\right)$ and very similar $S^{34}$ isotope values in the barites which accompany the mineralisations in both deposits. Due to this, a similar hydrothermal genesis for both, probably in a submarine environment, has been proposed (Martínez Frías 1992). This similitude in the genesis of the two deposits ought to be reflected in similarity and proximity in their isotopic fields.

The intensive mining of Herrerías makes the identification of copper samples difficult. In this article we present the trace element and lead isotope results for two samples of copper from Herrerías (one of them including native copper), and for two samples from Sierra Almagrera. These have to be added to four samples from Herrerías (three of native silver and one of copper) as well as 15 samples from Sierra Almagrera (5 of copper and 9 of galena) already published (Dayton and Dayton 1986; Arribas and Tosdal 1994; Stos-Gale et al. 1995; Bartelheim et al. 2012; OXALID).

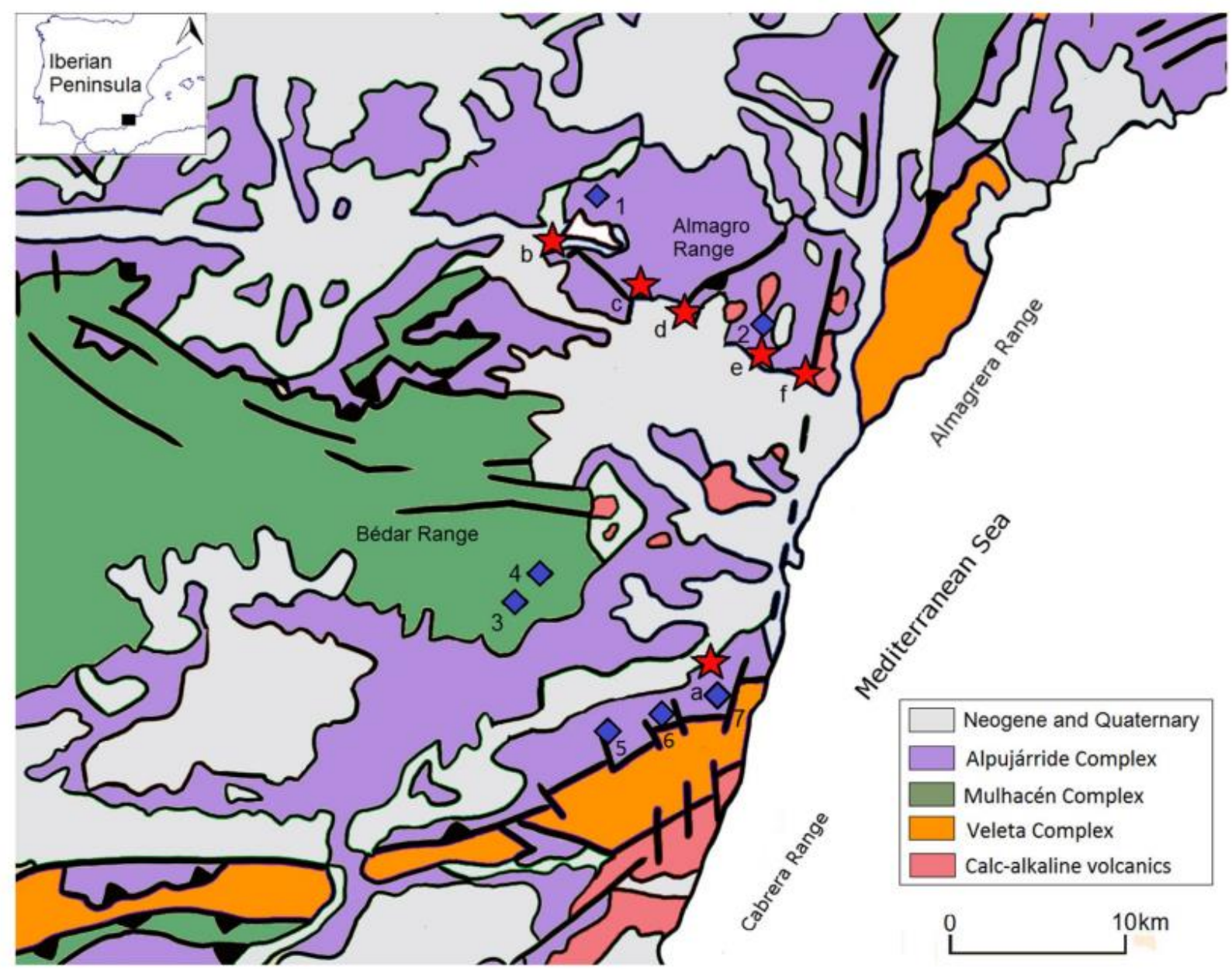

Fig. 4 Geological sketch map of SE Spain showing the location of ore samples (blue romboids: 1 Cerro Minado; 2 Herrerías; 3 and 4 Pinar de Bédar; 5, 6 and 7 Sierra Cabrera) and archaeological sites with metallurgical activity mentioned in the text (red stars: a, Las Pilas; b, Santa Bárbara; c, Campos; d, Zájara; e, Almizaraque; f, Cerro Virtud). Geological map modified from the 1:1,000,000 Geological Map of the Iberian Peninsula (IGME 2001) 


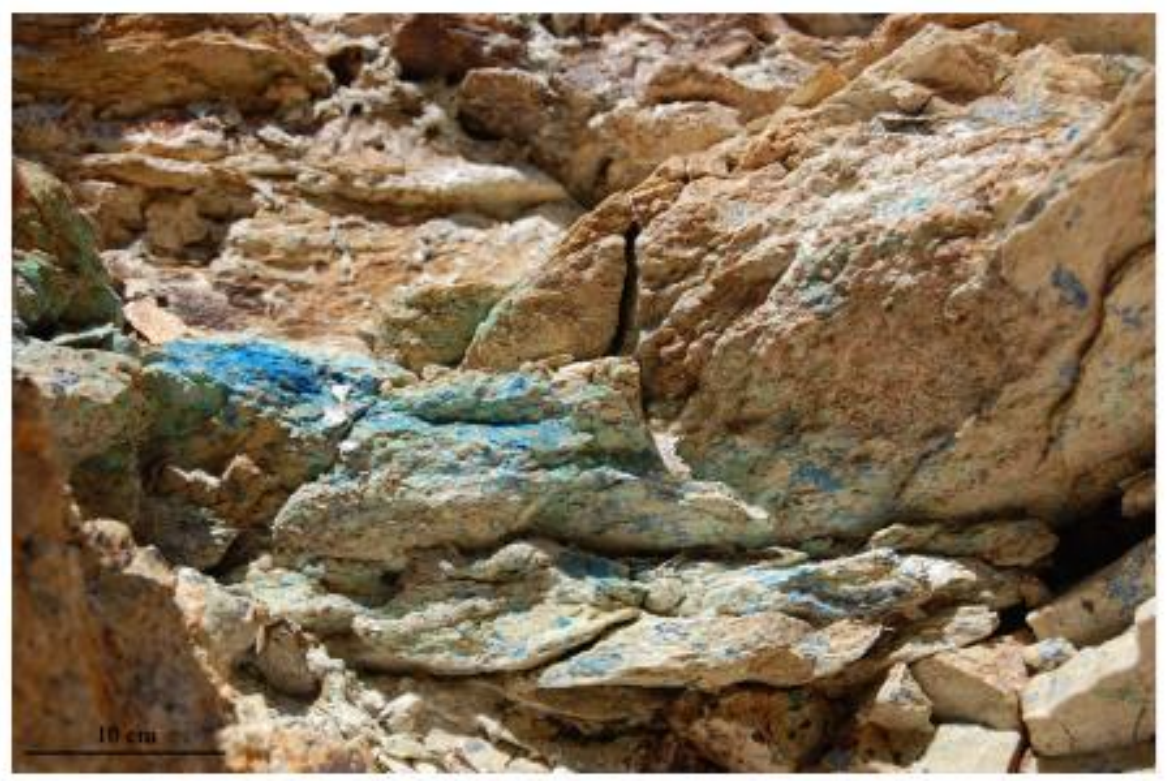

Fig. 5 Detail of copper outcrops from Sierra Cabrera
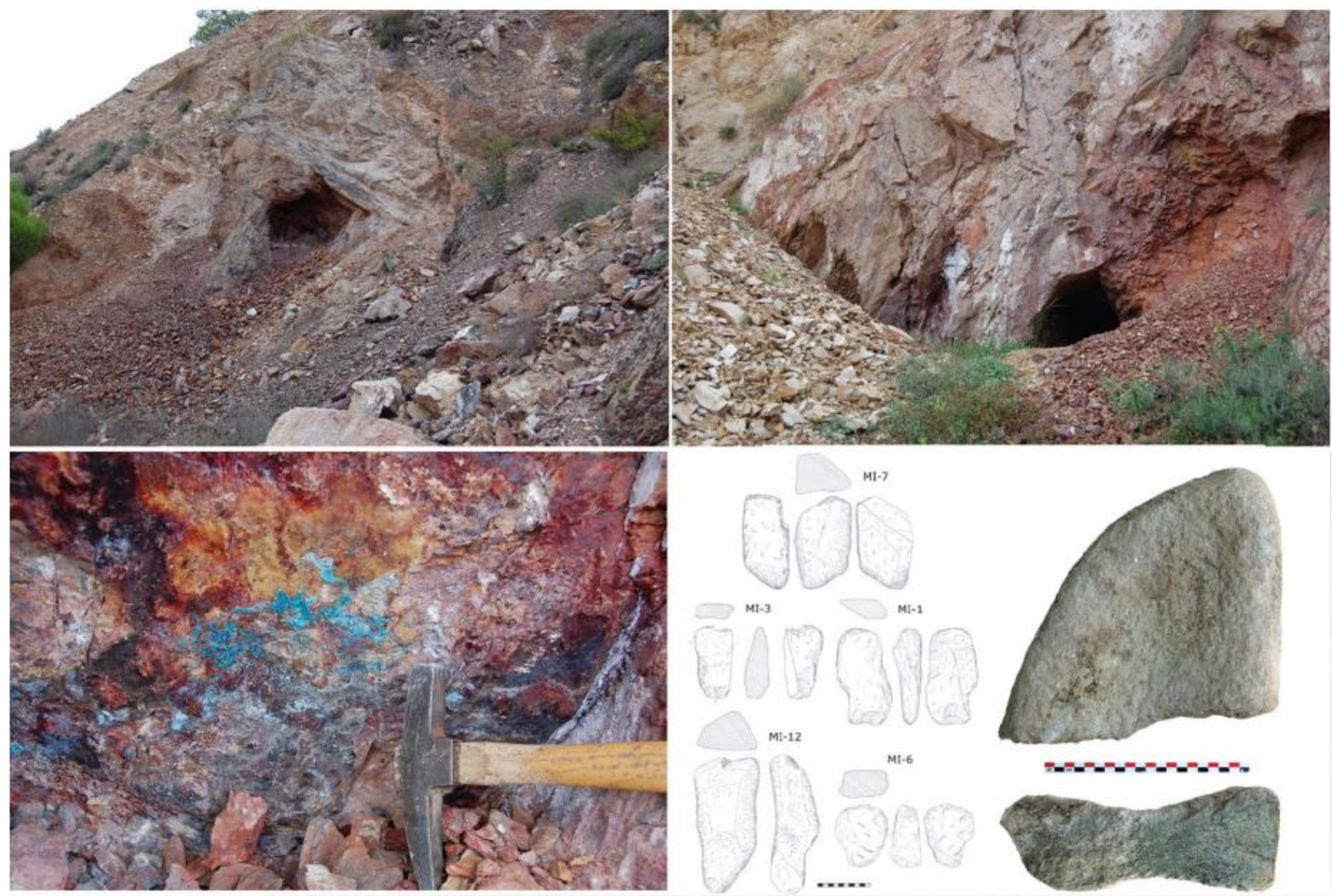
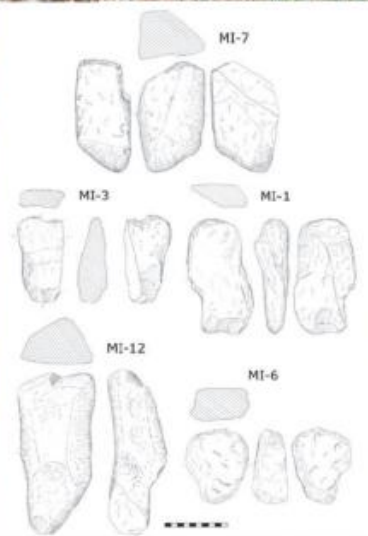
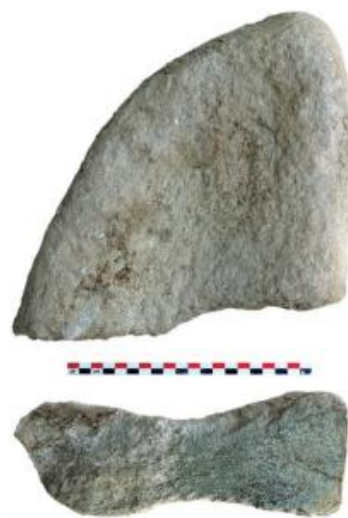

Fig. 6 Up: opencast mining from Cerro Minado. Left down: detail of copper outcrops from Cerro Minado. Right down: selection of prehistoric peaks and hammers recovered in Cerro Minado (Delgado Raak et al. 2014) and a mortar from Cerro Minado (Escanilla 2016) 


\subsection{Cerro Minado (Sierra de Almagro)}

To the north of the Vera depression is the Sierra de Almagro. Quaternary deposits constitute the base of the south-western part of the range on the western margin of the Almanzora river, while Tertiary loams form the greater part of the other margin. The Alpujárride Complex occupies almost the whole Sierra de Almagro. The predominant rocks in the different units are limestone, dolomite, phyllites and quartzites, although gypsum and diorites emerge with relative abundance between the phyllites, the first in the form of nodules and pockets, the second as small subvolcanic bodies (Simon 1963). In general two major tectonic units have been distinguished, a lower and an upper. In the lower, from bottom to top, we can separate a formation of Paleozoic mica schists, a formation of Permo-Triassic phyllite-quartzite, and a carbonated formation from the mid-upper Triassic. The upper unit is composed, basically, of schists and quartzites, phyllites and dolomites. The most attractive copper and cobalt ores in the whole Sierra de Almagro are found in this unit (IGME 1980).

The ores are found filling fissures in phyllites and dolomites with quartzites and calcschists. We are dealing with a stratiform and epigenetic deposit. The primary deposits of copper, cobalt, silver and mercury are found filling a dense network of fissures which is a consequence of, amongst other factors, the brecciation of the dolomites. This very brecciation has allowed the primary paragenesis to suffer an intense oxidizing and carbonating alteration. At Cerro Minado more than 100 types of minerals have been identified (Favreau et al. 2013), although the principal mining product of the Sierra de Almagro was iron. Nonetheless, as well as iron ores, we can recognise various sources of copper; among the most prominent are native copper, malachite, cuprite, olivenite etc.

In this range, the opencast mining of Cerro Minado is well known, with evidences of prehistoric works (Fig. 6). Domergue (1987) identified some stone mining tools and classified it as a Bronze Age mine, and recent surveys have documented stone peaks and hammers inside the mine (Delgado Raak et al. 2014). An absolute date, MAMS-18508 $3905 \pm 21$ BP (Delgado Raak et al. 2014) confirms its exploitation during the Copper Age, contemporaneous with the occupation of several sites in the area such as Almizaraque, Campos or Las Pilas.

The elemental composition of some geological samples reported high levels of arsenic (up to $42 \%)$ and the frequent occurrence of sulphidic phases, but the most characteristic feature of copper minerals from Cerro Minado is the typically high cobalt (up to $0.9 \%$ ) and nickel (up to 
1.2\%) (Favreau et al. 2013; Delgado Raak et al. 2014). This is due to the co-existence of erythrite $\left[\mathrm{Co}_{3}\left(\mathrm{AsO}_{4}\right)_{2} \cdot 8 \mathrm{H}_{2} \mathrm{O}\right]$ and annabergite $\left[\mathrm{Ni}_{3}\left(\mathrm{AsO}_{4}\right)_{2} \cdot 8 \mathrm{H}_{2} \mathrm{O}\right]$ with copper minerals and arsenates (Fig. 7). Native silver and $\mathrm{Hg}$-bearing silver have also been documented in Cerro Minado (Bertran-Oller et al. 2012; Favreau et al. 2013)—which is again consistent with the micro-analysis of some chalcolithic samples.

Therefore, we consider Cerro Minado to be one of the most important prehistoric mining districts in the area. While its mineralogy and composition has been amply studied (Favreau et al. 2013; Escanilla 2016) lead isotope analyses were scarce: only five analysed samples were available (Stos-Gale et al. 1995, 1999; OXALID). In this article we present the results of the lead isotope analysis of a further 16 samples, and of the ICP-MS elemental composition analysis of 10 of these.

\section{Materials and methods}

Elemental composition and lead isotope analysis (LIA) have been conducted on 34 samples of copper ores from these mining districts (Table 1). These results will be complemented with published analyses collected from literature. All samples were analysed at the Geochronology and Geochemistry Sglker-Facility of the University of the Basque Country UPV/EHU (Spain).

Trace element analysis of ore samples was done using an Inductively Coupled Plasma-Mass Spectrometer (ICP-MS). Reagent was concentrated $\mathrm{HNO}_{3}$ Merck Pro-Analysi further distilled in the laboratory by surface distillation using an Acidest quartz distiller. Deionized water was obtained using a Millipore Elix device and polished to obtain a resistivity $\geq 18 \mathrm{M} \mathrm{Ohm} \mathrm{cm}$ with a Barnstead EasyPure system. Rh solution, used as internal standard, and multielemental solutions for the initial tuning and calibration of the mass spectrometer, and for quality control (QC) of the results were prepared from 1000 ppm Merck multi-element standard solutions for ICP-MS, stabilized in $\mathrm{HNO}_{3} 2-6 \%$.

Internal standard was added by means of an automatic online addition kit in order to prevent random errors. Weighing to $0.1 \mathrm{mg}$ precision was done with an electronic balance GRAM SV 205A. The solution resulting of sequential multistep acid attack in Savillex PFA vessels and evaporation on heating plate was gravimetrically diluted to a factor adequate for the analysis. The elemental concentration was determined using a Thermo XSeries 2 inductively coupled plasma mass spectrometer (ICP-MS) equipped with collision cell (CCT), an interphase specific for 
elevated total dissolved solids (Xt cones) and shielded torch. A concentric nebulizer and quartz expansion chamber were employed. Further details on the instrumental method are given in García de Madinabeitia et al. (2008).

Error estimation for each element is established using the error propagation equation of Miller and Miller (2010). Uncertainty of the results corresponds to a 95\% confidence level.

Lead isotope analysis (LIA) was conducted via Multi-Collector Inductively-Coupled Plasma Mass Spectrometry (MC-ICP-MS) using a Neptune spectrometer. A thallium reference material NBS997 with a normalised ratio of $205 \mathrm{TI} / 203 \mathrm{TI}=2.3889$ was used for the internal mass correction (see Chernyshev et al. 2007 and references therein for further methodological questions). Reference material NBS981 Pb was also analysed to measure the accuracy of the instrument (Table 2). Standard deviation of all ratios is $<0.005(2 \sigma)$, analytical errors $( \pm 0.01 \%)$ smaller than symbols used in all graphs.

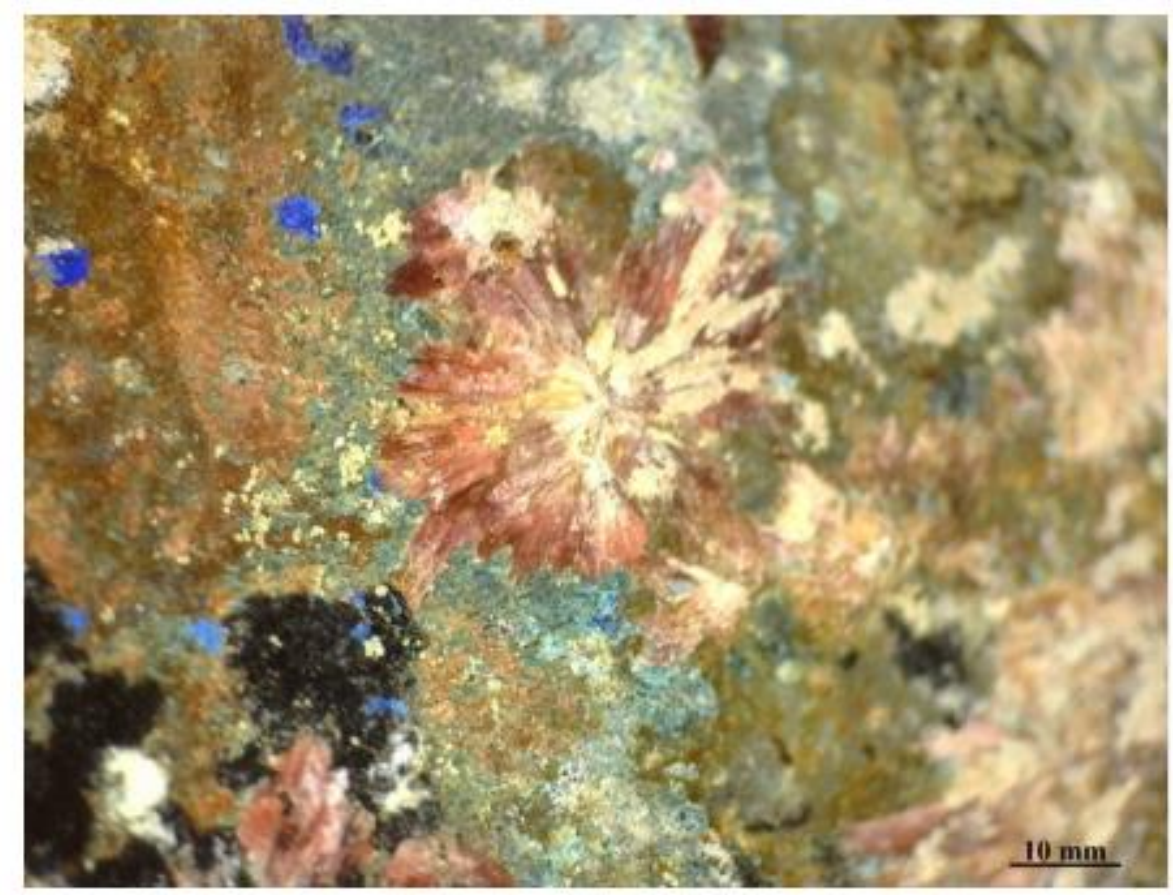

Fig. 7 Example of erithrin occurring together with malachite andazurite in one sample from Cerro Minado. Image: Mercedes Murillo-Barroso 


\section{Results}

\subsection{Elemental analysis}

The composition results revealed that most samples are heterogeneous copper ores, most of them with very high levels of arsenic, the exception being the samples from Sierra Cabrera, which stand out for their low levels of arsenic (Table 3). This is consistent with the XRD analysis of the samples PA24486, PA24488 and PA24490 from Cerro Minado, conducted at the University of the Basque Country, which identified olivenite $\left[\mathrm{Cu}_{2}+2\left(\mathrm{AsO}_{4}\right)(\mathrm{OH})\right]$, antlerite $\left[\mathrm{Cu}_{3}+2\left(\mathrm{SO}_{4}\right)(\mathrm{OH})_{4}\right]$ as well as dolomite from the gangue (Obón 2017).

The ores from Cerro Minado are characterised by their high cobalt and nickel content (with averages of $>1200$ and $>1400$ ppm respectively), something already detected in earlier studies (Montero Ruiz 1994) and which is further confirmed by the presence of erythrite and annabergite in the samples.

The deposits from Pinar de Bédar are characterised by their high levels of zinc and lead (c. 4\% $\mathrm{Zn}$ and $3.5 \% \mathrm{~Pb}$ on average, as compared to $0.4 \% \mathrm{Zn}$ and $30 \mathrm{ppm} \mathrm{Pb}$ from those at Cerro Minado, 270 ppm Zn and 30 ppm Pb at Sierra Cabrera or 600 ppm Zn and 500 ppm Pb at Herrerías). The data are in broad agreement with the overview yielded by the XRF analysis by Montero Ruiz (1994). The levels of arsenic in Pinar de Bédar are also higher compared to those of the rest of the deposits $(7.5 \%$ As on average compared to $2.5 \%$ in Cerro Minado, $1.5 \%$ in Herrerías or $0.5 \%$ in Sierra Cabrera), just as are those of bismuth ( $0.2 \%$ on average in Pinar de Bédar, which contrasts with $14 \mathrm{ppm}$ on average in Sierra Cabrera or $161 \mathrm{ppm}$ in Cerro Minado). Levels of silver and antimony are also considerably elevated in Pinar de Bédar (850 ppm Ag and 146 ppm Sb), Cerro Minado (117 ppm Ag and 207 ppm Sb) and Herrerías (306 ppm Ag and 226 ppm Sb) while they remain low in the samples from Sierra Cabrera (12 ppm Ag and $2 \mathrm{ppm} \mathrm{Sb}$ ). Nonetheless, up to now, there are references to the presence of native silver and its derivatives only at Herrerías and at Cerro Minado (Favreau et al. 2013; Murillo-Barroso et al. 2014).

As regards the levels of barium, they are significantly elevated in the samples from Pinar de Bédar and Herrerías ( $0.3 \% \mathrm{Ba}$ in both cases) while they remain around $30 \mathrm{ppm} \mathrm{Ba}$ in Cerro Minado and Sierra Cabrera. For their part, the ores from Herrerías show levels of iron significantly higher than the rest of the deposits as a consequence of the richness of this element in the area and the 
greater abundance of ferrous gangues as opposed to the dolomites of Cerro Minado or phyllites of Sierra Cabrera.

Finally we have to highlight the elevated levels of uranium at Pinar de Bédar (around $400 \mathrm{ppm} \mathrm{U}$ on average, with only $0.6 \mathrm{ppm}$ of Th) in contrast to the rest of the deposits, which are lower than $6 \mathrm{ppm}$ on average.

\subsection{Lead isotope analysis}

The whole range of lead isotope ratios of the ores sampled is from 18.554 to 20.327 for ${ }^{206} \mathrm{~Pb} / 204 \mathrm{~Pb}, 0.776$ to 0.843 for ${ }^{207} \mathrm{~Pb} /{ }^{206} \mathrm{~Pb}$ and 1.953 to 2.088 for ${ }^{208} \mathrm{~Pb} /{ }^{206} \mathrm{~Pb}$ (Table 4).

As described in the geological background, samples studied were recovered from two different complexes: the Mulhacén Complex (samples from Pinar de Bédar), and the Alpujárride Complex (samples from Sierra Cabrera, Cerro Minado and Herrerías/Almagrera). In this latter complex, copper samples were collected from different units: A phyllite formation from the Permo-Triassic in Sierra Cabrera; a stratiform and epigenetic unit composed of schists, quartzites, phyllites and dolomites in Cerro Minado where copper is found filling fissures and had suffered an intense oxidizing and carbonating alteration; and a venous and epigenetic unit with a hydrothermal genesis in Herrerías/Almagrera. Due to these differences we will consider Cerro Minado, Sierra Cabrera and Herrerías/Almagrera separately even if the three belong to the Alpujárride Complex.

Samples from Sierra Cabrera and Pinar de Bédar are grouped in a relatively well defined cluster with values between 18.808 and 18.904 for the ratio ${ }^{206} \mathrm{~Pb} / 204 \mathrm{~Pb}$, from 0.831 to 0.843 for ${ }^{207} \mathrm{~Pb} /{ }^{206} \mathrm{~Pb}$ and 2.067 to 2.078 for ${ }^{208} \mathrm{~Pb} /{ }^{206} \mathrm{~Pb}$ with the exception of one sample from Sierra Cabrera with very radiogenic values $\left(20.327\right.$ for the ratio ${ }^{206} \mathrm{~Pb} /{ }^{204} \mathrm{~Pb}, 0.776$ for ${ }^{207} \mathrm{~Pb} / 206 \mathrm{~Pb}$ and 1.953 for ${ }^{208} \mathrm{~Pb} /{ }^{206} \mathrm{~Pb}$ ), which we consider an outlier (possibly due to contamination from the rocks enclosing the deposit), and which does not appear in the graphs (Figs. 8, 9). 
Journal of Iberian Geology, 2019, pp 1-24

Table 1 List of samples analysed

\begin{tabular}{|c|c|c|c|c|}
\hline Area & ID & Sample & Trace elements & LIA \\
\hline Pinar de Bédar & BED 1 & Azurite and malachite. $\mathrm{CaCO}_{3}$ ? & $\mathrm{X}$ & $\mathrm{X}$ \\
\hline Pinar de Bédar & BED 2 & Malachite & $\mathrm{X}$ & $\mathrm{X}$ \\
\hline Pinar de Bédar & BED 3 & Malachite, azurite with iron oxide gangue & $\mathrm{X}$ & $\mathrm{X}$ \\
\hline Pinar de Bédar & BED 4 & Azurite & $\mathrm{X}$ & $\mathrm{X}$ \\
\hline Pinar de Bédar & BED 5 & Malachite, azurite with iron oxide gangue & $\mathrm{X}$ & $\mathrm{X}$ \\
\hline Pinar de Bédar & BED 6 & Azurite and malachite & $\mathrm{X}$ & $\mathrm{X}$ \\
\hline Pinar de Bédar & BED 7 & Azurite and malachite. $\mathrm{CaCO}_{3}$ ? & $\mathrm{X}$ & $\mathrm{X}$ \\
\hline Pinar de Bédar & BED 8 & Azurite and malachite & $\mathrm{X}$ & $\mathrm{X}$ \\
\hline Pinar de Bédar & BED 9 & Azurite and malachite & $\mathrm{X}$ & $\mathrm{X}$ \\
\hline Pinar de Bédar & BED 12 & Azurite and malachite & $\mathrm{X}$ & $\mathrm{X}$ \\
\hline Cerro Minado & CM 1 & Malachite & $\mathrm{X}$ & $\mathrm{X}$ \\
\hline Cerro Minado & $\mathrm{CM} 2$ & Malachite with phyllites gangue & $\mathrm{X}$ & $\mathrm{X}$ \\
\hline Cerro Minado & $\mathrm{CM} 3$ & Malachite and azurite & $\mathrm{X}$ & $\mathrm{X}$ \\
\hline Cerro Minado & $\mathrm{CM} 4$ & Malachite. Erithrite? & $\mathrm{X}$ & $\mathrm{X}$ \\
\hline Cerro Minado & CM 5 & Malachite. Erithrite? & $\mathrm{X}$ & $\mathrm{X}$ \\
\hline Cerro Minado & CM 6 & Azurite & $\mathrm{X}$ & $\mathrm{X}$ \\
\hline Cerro Minado & $\mathrm{CM} 7$ & Malachite with iron oxide gangue & $\mathrm{X}$ & $\mathrm{X}$ \\
\hline Cerro Minado & $\mathrm{CM} 8$ & Malachite with iron oxide gangue & $\mathrm{X}$ & $\mathrm{X}$ \\
\hline Cerro Minado & $\mathrm{CM} 9$ & Azurite and malachite & $\mathrm{X}$ & $\mathrm{X}$ \\
\hline Cerro Minado & $\mathrm{CM} 10$ & Azurite and malachite & $\mathrm{X}$ & $\mathrm{X}$ \\
\hline Cerro Minado & CM 11 & Azurite, siliceous gangue & $\mathrm{X}$ & $\mathrm{X}$ \\
\hline Cerro Minado & $\mathrm{CM} 12$ & Phyllites & $\mathrm{X}$ & $\mathrm{X}$ \\
\hline Cerro Minado & 1127/PA1577A & Azurite & & $\mathrm{X}$ \\
\hline Cerro Minado & PA24486 & Azurite, dolomite, malachite and mica & & $\mathrm{X}$ \\
\hline Cerro Minado & PA24488 & Azurite, olivenite, dolomite & & $\mathrm{X}$ \\
\hline Cerro Minado & PA24490 & Antlerite & & $\mathrm{X}$ \\
\hline Sierra Cabrera & MOJ-2 & Malachite and azurite. Phyllites gangue & $\mathrm{X}$ & $\mathrm{X}$ \\
\hline Sierra Cabrera & $\mathrm{CAB} 2$ & Malachite and azurite. Phyllites gangue & $\mathrm{X}$ & $\mathrm{X}$ \\
\hline Sierra Cabrera & $\mathrm{CAB} 3$ & Malachite and azurite. Phyllites gangue & $\mathrm{X}$ & $\mathrm{X}$ \\
\hline Sierra Cabrera & CAB 1_CR & Malachite and azurite. Phyllites gangue & $\mathrm{X}$ & $\mathrm{X}$ \\
\hline Herrerías & HERR_GUAD & Iron, copper carbonates and native copper & $\mathrm{X}$ & $\mathrm{X}$ \\
\hline Herrerías & HERR_22101 & Malachite with iron oxide gangue & $\mathrm{X}$ & $\mathrm{X}$ \\
\hline Almagrera & PA24467 & Malachite & & $\mathrm{X}$ \\
\hline Almagrera & PA24469 & Malachite & & $\mathrm{X}$ \\
\hline
\end{tabular}

Table 2 Analysis of the Standard NBS981

\begin{tabular}{llllllllllll}
\hline & ${ }^{206} \mathrm{~Pb} /{ }^{204} \mathrm{~Pb}$ & $2 \mathrm{SD}$ & ${ }^{207} \mathrm{~Pb} /{ }^{204} \mathrm{~Pb}$ & $2 \mathrm{SD}$ & ${ }^{208} \mathrm{~Pb} /{ }^{204} \mathrm{~Pb}$ & $2 \mathrm{SD}$ & ${ }^{208} \mathrm{~Pb} /{ }^{206} \mathrm{~Pb}$ & $2 \mathrm{SD}$ & ${ }^{207} \mathrm{~Pb} /{ }^{206} \mathrm{~Pb}$ & $2 \mathrm{SD}$ & $n$ \\
\hline NBS981 & 16.9432 & 0.0001 & 15.5007 & 0.0004 & 36.7285 & 0.0007 & 2.16774 & 0.00005 & 0.91486 & 0.00003 & 2 \\
\hline
\end{tabular}


Journal of Iberian Geology, 2019, pp 1-24

Table 3 Results of trace element composition analysis by MC-ICP-MS

\begin{tabular}{|c|c|c|c|c|c|c|c|c|c|}
\hline ID & $\mathrm{Na}(\mathrm{ppm})$ & $\mathrm{Mg}(\mathrm{ppm})$ & $\mathrm{Al}(\mathrm{ppm})$ & $\mathrm{P}$ (ppm) & $\mathbf{K}(\mathrm{ppm})$ & $\mathrm{Ca}(\mathrm{ppm})$ & $\mathrm{Sc}(\mathrm{ppm})$ & $\mathrm{Ti}(\mathrm{ppm})$ & V (ppm) \\
\hline \multicolumn{10}{|l|}{ Cerro Minado } \\
\hline CM1 & 897.7 & 8357 & 1044 & 393.9 & 3436 & 2335 & 0.3801 & 7.437 & 11.19 \\
\hline $\mathrm{CM} 2$ & 99.81 & 300.5 & 6015 & 320.7 & 2590 & 125.9 & 2.164 & 8.636 & 6.711 \\
\hline $\mathrm{CM} 3$ & 131.5 & 31,210 & 4895 & 170.5 & 2842 & 7776 & 2.051 & 9.806 & 9.622 \\
\hline CM4 & 404.3 & 77,710 & 764.5 & 41.28 & 370.2 & 24,180 & 0.4886 & 6.445 & 10.99 \\
\hline CM5 & 89.07 & 1188 & 4362 & 566.6 & 2676 & 441.3 & 2.569 & 4.602 & 10.49 \\
\hline CM6 & 115.1 & 91,790 & 531.8 & 28.69 & 223.6 & 22,430 & 0.5123 & 2.804 & 21.63 \\
\hline $\mathrm{CM} 7$ & 86.6 & 1990 & 213.3 & 128.8 & 60.51 & 644.9 & 0.1854 & 1.232 & 34.07 \\
\hline $\mathrm{CM} 8$ & 36.9 & 11,360 & 383.5 & 18.48 & 139.3 & 2728 & 0.2251 & 3.283 & 2.363 \\
\hline CM9 & 109.5 & 10,030 & 229.6 & 17.15 & 143.9 & 7347 & 0.2351 & 2.026 & 7.511 \\
\hline CM10 & 108.8 & 77,580 & 627.3 & 63.64 & 318.2 & 19,840 & 0.3918 & 5.65 & 7.492 \\
\hline CM11 & 132.4 & 79,000 & 300.2 & 14.11 & 142 & 20,180 & 0.3097 & 2.91 & 4.467 \\
\hline Average & 201.1 & $35,501.4$ & 1760.6 & 160.3 & 1176.5 & 9820.7 & 0.865 & 4.985 & 11.503 \\
\hline St deviation & 249.7 & $37,601.9$ & 2185.4 & 186.9 & 1374.0 & 9775.9 & 0.911 & 2.830 & 8.971 \\
\hline \multicolumn{10}{|l|}{ Pinar de Bédar } \\
\hline BED_1 & 41.66 & 2178 & 178.4 & 74.84 & 997.5 & 15,820 & 0.685 & 1.505 & 17.13 \\
\hline BED_2 & 89.31 & 8598 & 3190 & 711.1 & 847 & 2188 & 1.657 & 76.15 & 15.64 \\
\hline BED_3 & 57.7 & 64,850 & 249.1 & 140.4 & 73.37 & 10,930 & 1.655 & 6.699 & 84.81 \\
\hline BED_4 & 45.87 & 1037 & 117.6 & 57.48 & 22.71 & 297.3 & 0.376 & 1.565 & 12.1 \\
\hline BED_5 & 145.3 & 10,350 & 474.3 & 135 & 241.9 & 3907 & 1.022 & 6.874 & 26.52 \\
\hline BED_6 & 45.44 & 10,150 & 225.8 & 80.36 & 293.4 & 1949 & 0.503 & 2.629 & 19.86 \\
\hline BED_7 & 50.47 & 15,780 & 278.4 & 121.2 & 175.9 & 2814 & 0.516 & 2.409 & 8.162 \\
\hline BED_8 & 49.23 & 15,610 & 269.7 & 115.5 & 170.9 & 2786 & 0.401 & 2.464 & 7.963 \\
\hline BED_9 & 88.62 & 7519 & 3058 & 143.8 & 679.9 & 1303 & 3.532 & 26.71 & 34.16 \\
\hline BED_12 & 70.14 & 2938 & 83.71 & 198.4 & 69.71 & 16,880 & 2.856 & 0.994 & 58.58 \\
\hline Average & 68.4 & $13,901.0$ & 812.5 & 177.8 & 357.2 & 5887.4 & 1.320 & 12.800 & 28.5 \\
\hline St deviation & 32.2 & 18621.6 & 1223.2 & 191.7 & 351.8 & 6230.5 & 1.107 & 23.548 & 24.1 \\
\hline ID & $\mathrm{Na}(\mathrm{ppm})$ & $\mathrm{Mg}(\mathrm{ppm})$ & $\mathrm{Al}$ (ppm) & $\mathrm{P}$ (ppm) & $\mathrm{K}(\mathrm{ppm})$ & $\mathrm{Ca}(\mathrm{ppm})$ & Sc (ppm) & $\mathrm{Ti}(\mathrm{ppm})$ & V (ppm) \\
\hline \multicolumn{10}{|l|}{ Sierra Cabrera } \\
\hline CAB1_CR & 892.9 & 9658 & 16,080 & 211.7 & 2164 & 143.4 & 1.187 & 14.57 & 10.94 \\
\hline MOJ_2 & 305.3 & 12,290 & 20,330 & 279.6 & 5204 & 139.6 & 1.967 & 22.09 & 16.15 \\
\hline CAB_2 & 780.9 & 22,820 & 39,890 & 753.2 & 1926 & 314.8 & 3.106 & 5.02 & 42.65 \\
\hline CAB_3 & 205.2 & 2266 & 3101 & 245.2 & 1124 & 340.5 & 0.764 & 2.377 & 6.874 \\
\hline Average & 546.1 & $11,758.5$ & $19,850.2$ & 372.4 & 2604.5 & 234.6 & 1.756 & 11.014 & 19.1 \\
\hline St deviation & 341.4 & 8508.0 & 15237.8 & 255.3 & 1789.2 & 108.0 & 1.029 & 9.053 & 16.1 \\
\hline \multicolumn{10}{|l|}{ Herrerías } \\
\hline HERR_GUAD & 1647 & 471.7 & 1282 & 95.38 & 204.3 & 626.1 & 0.308 & 41.69 & 11.76 \\
\hline HERR_22101 & 1046 & 940.7 & 287.8 & 80.97 & 2731 & 441.7 & 0.883 & 0.293 & 30.56 \\
\hline Average & 1346.5 & 706.2 & 784.9 & 88.2 & 1467.6 & 533.9 & 0.596 & 20.992 & 21.1 \\
\hline St deviation & 425.0 & 331.6 & 703.0 & 10.2 & 1786.6 & 130.4 & 0.407 & 29.272 & 13.3 \\
\hline ID & $\mathrm{Cr}(\mathrm{ppm})$ & $\mathrm{Fe}$ (ppm) & Mn (ppm) & $\mathrm{Co}(\mathrm{ppm})$ & $\mathrm{Ni}$ (ppm) & $\mathrm{Cu}(\%)$ & Zn (ppm) & As (ppm) & $\begin{array}{l}\text { Rb } \\
\text { (ppm) }\end{array}$ \\
\hline \multicolumn{10}{|l|}{ Cerro Minado } \\
\hline CM1 & 1.524 & 43,350 & 393.5 & 3368 & 5313 & 22.36 & 7913 & 168,500 & 3.12 \\
\hline $\mathrm{CM} 2$ & 5.028 & 4329 & 17.95 & 211.2 & 566.6 & 10.32 & 2969 & 1106 & 9.077 \\
\hline $\mathrm{CM}_{3}$ & 5.961 & 6318 & 447.8 & 1591 & 1870 & 26.09 & 22,220 & nd & 7.205 \\
\hline CM4 & 5.15 & 2986 & 391.8 & 200.2 & 230.7 & 15.47 & 2465 & 483.5 & 0.9774 \\
\hline CM5 & 5.159 & 7436 & 28.14 & 114.8 & 266 & 23.21 & 2115 & 3847 & 8.055 \\
\hline CM6 & 1.31 & 8146 & 831.3 & 1742 & 2551 & 11.92 & 1537 & 13,300 & 0.6792 \\
\hline
\end{tabular}


Journal of Iberian Geology, 2019, pp 1-24

Table 3 (continued)

\begin{tabular}{|c|c|c|c|c|c|c|c|c|c|c|c|c|c|}
\hline \multicolumn{2}{|l|}{ ID } & $\mathrm{Cr}(\mathrm{ppm})$ & \multicolumn{2}{|c|}{$\mathrm{Fe}(\mathrm{ppm})$} & \multicolumn{2}{|c|}{ Mn (ppm) } & Co (ppm) & $\mathrm{Ni}(\mathrm{ppm})$ & $\mathrm{Cu}(\%)$ & & $\mathrm{Zn}(\mathrm{ppm})$ & As (ppm) & $\begin{array}{l}\mathrm{Rb} \\
\text { (ppm) }\end{array}$ \\
\hline \multicolumn{2}{|l|}{ CM7 } & \multicolumn{3}{|l|}{0.4903} & \multicolumn{2}{|c|}{194.5} & 1795 & 1697 & 22.98 & & 1978 & 26,790 & 0.1893 \\
\hline \multicolumn{2}{|l|}{ CM8 } & \multicolumn{3}{|l|}{0.7923} & \multicolumn{2}{|c|}{97.54} & 53.02 & 154 & 16.65 & & 1349 & 776.7 & 0.6029 \\
\hline \multicolumn{2}{|l|}{ CM9 } & \multicolumn{3}{|c|}{15,490} & \multicolumn{2}{|c|}{308.9} & 3280 & 2574 & 13.24 & & 4378 & 51,250 & 0.3862 \\
\hline \multicolumn{2}{|l|}{ CM10 } & 0.8432 & 10,280 & & 640 & & 1040 & 742.9 & 3.333 & & 684.6 & 3414 & 0.9398 \\
\hline CM11 & & 0.795 & 6568 & & 827 & & 261.1 & 374.1 & 0.9046 & & 53.77 & 2541 & 0.3534 \\
\hline Average & & 2.521 & $10,331$. & & 379 & & 1241.5 & 1485.4 & 15.1 & & 4333.0 & $24,728.0$ & 2.9 \\
\hline St deviation & & 2.253 & $11,508$. & & 291 & & 1232.3 & 1569.3 & 8.2 & & 6300.2 & $50,221.6$ & 3.5 \\
\hline Pinar de Béda & & & & & & & & & & & & & \\
\hline BED_1 & & 1.647 & 7464 & & 29.9 & & 29.45 & 102.6 & 23.16 & & 31,740 & 67,290 & 0.161 \\
\hline BED_2 & & 11.51 & 801.9 & & 6.09 & & 10.91 & 203.2 & 48.45 & & 7391 & 4854 & 3.056 \\
\hline BED_3 & & 8.724 & 2196 & & 43.0 & & 8.892 & 84.43 & 23.42 & & 8162 & 27,150 & 0.266 \\
\hline BED_4 & & 0.103 & 226.7 & & 51.6 & & 38.9 & 89.23 & 23.98 & & 102,200 & 156,100 & 0.119 \\
\hline BED_5 & & 15.26 & 2876 & & 3.04 & & 13.8 & 104.9 & 9.943 & & 15930 & 101,500 & 1.084 \\
\hline BED_6 & & 2.143 & 2609 & & 24.6 & & 48.36 & 186.7 & 46.39 & & 32,450 & 69,640 & 0.183 \\
\hline BED_7 & & 2.507 & 972.2 & & 29.3 & & 58.17 & 205.6 & 40.04 & & 37040 & 68,120 & 0.748 \\
\hline BED_8 & & 2.367 & 964.6 & & 27.0 & & 57.48 & 205.3 & 40.3 & & 36,910 & 66,790 & 0.664 \\
\hline BED_9 & & 5.779 & 4555 & & 14.4 & & 90.25 & 175.7 & 69.33 & & 22,490 & 6399 & 3.037 \\
\hline BED_12 & & 0.822 & 4699 & & 159 & & 87.68 & 138.2 & 24.77 & & 104,600 & 191,100 & nd \\
\hline Average & & 5.086 & 2736.4 & & 38.8 & & 44.4 & 149.6 & 35.0 & & $39,891.3$ & $75,894.3$ & 0.9 \\
\hline St deviation & & 5.121 & 2263.9 & & 44.9 & & 29.7 & 51.0 & 17.2 & & $35,195.3$ & $60,433.4$ & 1.1 \\
\hline ID & & $\mathrm{Cr}$ (ppm) & $\mathrm{Fe}(\mathrm{pp}$ & & $\mathrm{Mn}(\mathrm{P}$ & ppm) & $\mathrm{Co}$ (ppm) & $\mathrm{Ni}(\mathrm{ppm})$ & $\mathrm{Cu}(\%)$ & & $\mathrm{Zn}(\mathrm{ppm})$ & As (ppm) & $\mathrm{Rb}(\mathrm{ppm})$ \\
\hline Sierra Cabrer & & & & & & & & & & & & & \\
\hline CAB1_CR & & 8.556 & 5474 & & 48.14 & & 6.192 & 10.87 & 0.7107 & & 187.6 & 1109 & 7.958 \\
\hline MOJ_2 & & 41.84 & 11,07 & & 167.7 & & 12.75 & 37.72 & 11.55 & & 627.7 & 305.7 & 19.59 \\
\hline CAB_2 & & 34.46 & $23,50 x$ & & 171.3 & & 32.56 & 69.02 & 5.827 & & 203.8 & 195.7 & 10.51 \\
\hline CAB_3 & & 4.151 & 4645 & & 90.46 & & 13.48 & 32.41 & 1.925 & & 85.63 & 210.4 & 3.941 \\
\hline Average & & 22.252 & 11172 & & 119.4 & & 16.2 & 37.5 & 5.0 & & 276.2 & 455.2 & 10.5 \\
\hline St deviation & & 18.690 & 8699.8 & & 60.4 & & 11.4 & 24.0 & 4.9 & & 240.1 & 438.6 & 6.6 \\
\hline Herrerías & & & & & & & & & & & & & \\
\hline HERR_GU $F$ & & 4.533 & 80,86 & & 1259 & & 2.269 & 0.886 & 6.156 & & 171.2 & 50.61 & 0.82 \\
\hline HERR_221C & & 0.696 & 49,12 & & 70.46 & & 181.6 & 521.5 & 13.53 & & 1055 & 29,860 & 1.014 \\
\hline Average & & 2.615 & 64,99 & & 664.7 & & 91.9 & 261.2 & 9.8 & & 513.1 & $14,955.3$ & 0.9 \\
\hline St deviation & & 2.713 & 22443 & & 840.4 & & 126.8 & 368.1 & 5.2 & & 624.9 & $21,078.4$ & 0.1 \\
\hline ID & $\begin{array}{l}\mathrm{Sr} \\
(\mathrm{ppm})\end{array}$ & $\begin{array}{l}Y \\
\text { (ppm) }\end{array}$ & $\mathrm{Ag}(\mathrm{ppm})$ & $\mathrm{Sb}$ & (ppm) & $\mathrm{Ba}(\mathrm{ppm})$ & 1) La (ppm) & $\mathrm{Ce}$ (ppm) & $\operatorname{Pr}(\mathrm{ppm})$ & $\begin{array}{l}\text { Nd } \\
\text { (ppm) }\end{array}$ & $\begin{array}{l}\text { Sm } \\
(\mathrm{ppm})\end{array}$ & $\begin{array}{l}\text { Eu } \\
\text { (ppm) }\end{array}$ & Gd (ppm) \\
\hline Cerro Minado & & & & & & & & & & & & & \\
\hline CM1 & 135 & 2.02 & 397.7 & 105 & & 216.8 & 1.59 & 2.71 & 0.39 & 1.18 & 0.34 & 0.19 & 0.43 \\
\hline $\mathrm{CM} 2$ & 29.63 & 5.923 & 2.537 & 8.21 & & 14.86 & 27.22 & 60.95 & 7.56 & 28.31 & 5.61 & 0.9 & 4.14 \\
\hline CM3 & 35.9 & 2.135 & 160.7 & 9.47 & & 16.64 & 9.22 & 15.45 & 1.42 & 4.36 & 0.57 & 0.09 & 0.54 \\
\hline CM4 & 48.87 & 1.39 & 5.264 & 27.6 & & 6.228 & 0.85 & 1.56 & 0.18 & 0.66 & 0.15 & nd & 0.18 \\
\hline CM5 & 13.59 & 1.66 & 1.881 & 3.97 & & 27.11 & 13.03 & 26.97 & 2.87 & 10.56 & 2.02 & 0.34 & 1.35 \\
\hline CM6 & 137 & 2.198 & 405.3 & 242 & & 76.58 & 2.09 & 3.63 & 0.4 & 1.55 & 0.36 & 0.1 & 0.47 \\
\hline CM7 & 38.32 & 0.7023 & 10.28 & 158 & & 8.144 & 0.25 & 0.42 & 0.1 & 0.23 & 0.1 & nd & 0.13 \\
\hline CM8 & 11.64 & 0.5745 & 0.5445 & 80.1 & & 7.066 & 0.57 & 1.24 & 0.15 & 0.58 & 0.14 & nd & 0.15 \\
\hline СM9 & 60.75 & 0.8051 & 282.8 & 604 & & 2.361 & 0.53 & 1.04 & 0.11 & 0.38 & 0.11 & nd & 0.21 \\
\hline CM10 & 62.23 & 1.157 & 19.87 & 81.6 & & 9.38 & 1.07 & 1.88 & 0.2 & 0.76 & 0.17 & nd & 0.22 \\
\hline CM11 & 84.5 & 0.7715 & 5.486 & 15.8 & & 4.25 & 0.5 & 1.02 & 0.12 & 0.48 & 0.13 & nd & 0.17 \\
\hline Average & 59.7 & 1.7 & 117.5 & 207 & & 35.4 & 5.1 & 10.6 & 1.2 & 4.4 & 0.9 & 0.1 & 0.7 \\
\hline
\end{tabular}


Journal of Iberian Geology, 2019, pp 1-24

Table 3 (continued)

\begin{tabular}{|c|c|c|c|c|c|c|c|c|c|c|c|c|}
\hline ID & $\begin{array}{l}\mathrm{Sr} \\
\text { (ppm) }\end{array}$ & $\begin{array}{l}\mathrm{Y} \\
\text { (ppm) }\end{array}$ & $\mathrm{Ag}$ (ppm) & $\mathrm{Sb}(\mathrm{ppm})$ & $\mathrm{Ba}(\mathrm{ppm})$ & $\mathrm{La}$ (ppm) & $\mathrm{Ce}$ (ppm) & $\operatorname{Pr}(\mathrm{ppm})$ & $\begin{array}{l}\text { Nd } \\
\text { (ppm) }\end{array}$ & $\begin{array}{l}\text { Sm } \\
\text { (ppm) }\end{array}$ & $\begin{array}{l}\text { Eu } \\
(\mathrm{ppm})\end{array}$ & Gd (ppm) \\
\hline St deviation & 43.3 & 1.5 & 166.4 & 330.8 & 63.7 & 8.4 & 18.6 & 2.2 & 8.5 & 1.6 & 0.3 & 1.2 \\
\hline \multicolumn{13}{|l|}{ Pinar de Bédar } \\
\hline BED_1 & 98.29 & 1.785 & 9.809 & 248 & 9557 & 1.082 & 0.566 & 0.159 & 0.436 & 0.203 & 0.638 & 0.23 \\
\hline BED_2 & 932.2 & 16.56 & 2218 & 31.96 & 1534 & 25.57 & 35.2 & 4.736 & 17.87 & 5.226 & 1.465 & 4.053 \\
\hline BED_3 & 120.9 & 7.849 & 1867 & 29.21 & 105.6 & 1.115 & 2.705 & 0.629 & 3.134 & 1.282 & 0.37 & 1.158 \\
\hline BED_4 & 116.3 & 0.6 & 13.88 & 82.63 & 8266 & 0.856 & 0.311 & nd & 0.123 & nd & 0.447 & nd \\
\hline BED_5 & 809.2 & 2.2 & 97.03 & 208.5 & 3343 & 0.945 & 0.804 & 0.138 & 0.609 & 0.153 & 0.306 & 0.178 \\
\hline BED_6 & 47.41 & 1.998 & 1912 & 231.2 & 1849 & 0.729 & 0.888 & 0.139 & 0.609 & 0.158 & 0.13 & 0.166 \\
\hline BED_7 & 55.33 & 1.348 & 162.3 & 131.4 & 1838 & 0.665 & 0.757 & 0.176 & 0.49 & 0.18 & 0.193 & 0.197 \\
\hline BED_8 & 53.94 & 1.264 & 161.8 & 128.6 & 1798 & 0.559 & 0.667 & 0.096 & 0.43 & 0.093 & 0.111 & 0.109 \\
\hline BED_9 & 41.19 & 13.42 & 2020 & 136.7 & 267.1 & 1.471 & 4.036 & 1.178 & 5.868 & 2.376 & 0.684 & 2.107 \\
\hline BED_12 & 66.34 & 2.9 & 46.68 & 232.7 & 2611 & 0.699 & 0.901 & 0.227 & 0.993 & 0.302 & 0.22 & 0.288 \\
\hline Average & 234.1 & 4.9 & 850.8 & 146.1 & 3116.9 & 3.4 & 4.7 & 0.7 & 3.0 & 0.9 & 0.4 & 0.8 \\
\hline $\begin{array}{l}\text { St Desvia- } \\
\text { tion }\end{array}$ & 337.9 & 5.7 & 998.1 & 81.9 & 3214.1 & 7.8 & 10.8 & 1.4 & 5.5 & 1.6 & 0.4 & 1.3 \\
\hline \multicolumn{13}{|l|}{ Sierra Cabrera } \\
\hline CAB1_CR & 95.42 & 2.246 & 0.639 & 1.817 & 27.71 & 10.5 & 22.79 & 2.643 & 9.952 & 1.809 & 0.238 & 1.24 \\
\hline MOJ_2 & 15.35 & 3.797 & 2.491 & 4.708 & 42.9 & 0.688 & 2.162 & 0.377 & 2.304 & 1.351 & 0.315 & 1.445 \\
\hline CAB_2 & 24.54 & 2.572 & 43.3 & 0.37 & 63.08 & 0.478 & 2.038 & 0.427 & 2.848 & 1.861 & 0.469 & 1.74 \\
\hline CAB_3 & 12.19 & 2.077 & 1.321 & 0.974 & 13.95 & 0.157 & 0.575 & 0.12 & 0.853 & 0.719 & 0.184 & 0.979 \\
\hline Average & 36.9 & 2.7 & 11.9 & 1.9 & 36.9 & 2.9 & 6.9 & 0.9 & 3.9 & 1.4 & 0.3 & 1.3 \\
\hline St deviation & 39.4 & 0.7 & 20.9 & 1.9 & 21.1 & 5.0 & 10.6 & 1.2 & 4.0 & 0.5 & 0.1 & 0.3 \\
\hline \multicolumn{13}{|l|}{ Herrerías } \\
\hline $\begin{array}{l}\text { HERR_ } \\
\text { GUAD }\end{array}$ & 232.6 & 2.265 & 72.48 & 19.8 & 6039 & 2.104 & 3.964 & 0.487 & 1.951 & 0.579 & 4.728 & 0.633 \\
\hline $\begin{array}{r}\text { HERR_ } \\
22101\end{array}$ & 101.5 & 2.081 & 539.9 & 432.5 & 72.6 & 1.247 & 2.593 & 0.314 & 1.104 & 0.266 & 0.102 & 0.368 \\
\hline Average & 167.0 & 2.2 & 306.2 & 226.1 & 3055.8 & 1.7 & 3.3 & 0.4 & 1.5 & 0.4 & 2.4 & 0.5 \\
\hline St deviation & 92.7 & 0.1 & 330.5 & 291.8 & 4218.9 & 0.6 & 0.9 & 0.1 & 0.6 & 0.2 & 3.3 & 0.2 \\
\hline ID & $\mathrm{Tb}(\mathrm{p}$ & ppm) & Dy (ppm) & Ho (ppm) & $\mathrm{Er}(\mathrm{ppm})$ & $\operatorname{Tm}(\mathrm{ppm})$ & $\mathrm{Yb}(\mathrm{ppm})$ & Lu (ppm) & $\mathrm{Pb}(\mathrm{ppm})$ & $\mathrm{Bi}(\mathrm{ppm})$ & Th (ppm) & U (ppm) \\
\hline \multicolumn{13}{|l|}{ Cerro Minado } \\
\hline CM1 & 0.15 & & 0.38 & 0.15 & 0.24 & 0.12 & 0.21 & 0.11 & 146 & 1133 & 0.3 & 2.92 \\
\hline $\mathrm{CM} 2$ & 0.41 & & 1.75 & 0.28 & 0.71 & 0.1 & 0.58 & 0.08 & 2.99 & 7.9 & 14.53 & 0.24 \\
\hline CM3 & nd & & 0.38 & nd & 0.24 & nd & 0.28 & nd & 16.5 & 11.89 & 1.65 & 2.56 \\
\hline CM4 & nd & & 0.19 & nd & 0.13 & nd & 0.12 & nd & 3.62 & 2.77 & 0.18 & 2.06 \\
\hline CM5 & 0.13 & & 0.57 & 0.09 & 0.23 & nd & 0.19 & nd & 5.32 & 2.47 & 4 & 0.57 \\
\hline CM6 & nd & & 0.38 & nd & 0.18 & nd & 0.17 & nd & 111.7 & 213.6 & 0.27 & 4.77 \\
\hline CM7 & nd & & 0.13 & nd & 0.1 & nd & 0.09 & nd & 19.12 & 80.3 & 0.14 & 2.7 \\
\hline CM8 & nd & & 0.13 & nd & nd & nd & nd & nd & 2.17 & 9.98 & 0.16 & 1.2 \\
\hline CM9 & nd & & 0.18 & nd & nd & nd & nd & nd & 35.85 & 283.8 & 0.17 & 2.01 \\
\hline CM10 & nd & & 0.19 & nd & 0.1 & nd & nd & nd & 27.63 & 22.88 & 0.2 & 1.43 \\
\hline CM11 & nd & & 0.15 & nd & nd & nd & nd & nd & 6.45 & 5.52 & 0.12 & 0.9 \\
\hline Average & 0.0 & & 0.4 & 0.0 & 0.2 & 0.0 & 0.1 & 0.0 & 34.3 & 161.3 & 1.9 & 1.9 \\
\hline St deviation & 0.1 & & 0.4 & 0.1 & 0.2 & 0.0 & 0.1 & 0.0 & 48.6 & 336.3 & 4.3 & 1.3 \\
\hline \multicolumn{13}{|l|}{ Pinar de Bédar } \\
\hline BED_1 & 0.097 & & 0.255 & 0.109 & 0.191 & 0.088 & 0.175 & 0.088 & 9981 & 28.5 & 0.151 & 142.4 \\
\hline BED_2 & 0.907 & & 5.945 & 0.999 & 2.775 & 0.39 & 2.62 & 0.247 & 1212 & 2604 & 3.311 & 1152 \\
\hline
\end{tabular}


Journal of Iberian Geology, 2019, pp 1-24

Table 3 (continued)

\begin{tabular}{llllllllllll}
\hline ID & Tb (ppm) & Dy (ppm) & Ho (ppm) & Er (ppm) & $\mathrm{Tm}(\mathrm{ppm})$ & $\mathrm{Yb}(\mathrm{ppm})$ & $\mathrm{Lu}(\mathrm{ppm})$ & $\mathrm{Pb}(\mathrm{ppm})$ & $\mathrm{Bi}(\mathrm{ppm})$ & $\mathrm{Th}(\mathrm{ppm})$ & $\mathrm{U}(\mathrm{ppm})$ \\
\hline BED_3 & 0.264 & 1.881 & 0.336 & 1.007 & 0.142 & 0.998 & 0.106 & 9601 & 10200 & 0.692 & 259.4 \\
BED_4 & nd & nd & nd & nd & nd & nd & nd & 5462 & 18.12 & nd & 276.4 \\
BED_5 & nd & 0.165 & nd & 0.089 & nd & nd & nd & 261,500 & 22.15 & nd & 121.6 \\
BED_6 & nd & 0.213 & nd & 0.146 & nd & 0.136 & nd & 6431 & 115.5 & 0.224 & 354.7 \\
BED_7 & 0.088 & 0.22 & 0.102 & 0.174 & 0.084 & 0.165 & 0.079 & 7752 & 35.52 & 0.172 & 199.4 \\
BED_8 & nd & 0.139 & nd & 0.096 & nd & 0.091 & nd & 7764 & 35.56 & 0.109 & 198 \\
BED_9 & 0.497 & 3.692 & 0.695 & 2.264 & 0.36 & 2.753 & 0.3 & 4000 & 9030 & 1.765 & 553.2 \\
BED_12 & nd & 0.53 & 0.098 & 0.319 & nd & 0.33 & nd & 25,640 & 294.7 & nd & 861.1 \\
Average & 0.1 & 1.3 & 0.2 & 0.7 & 0.1 & 0.7 & 0.8 & $33,934.3$ & 2238.4 & 0.6 & 411.8 \\
St Deviation & 0.3 & 2.0 & 0.3 & 1.0 & 0.1 & 1.1 & 0.1 & $80,225.4$ & 3977.2 & 1.0 & 343.5 \\
Sierra Cabrera & & & & & & & & & & & \\
CAB1_CR & 0.134 & 0.608 & 0.093 & 0.228 & nd & 0.163 & nd & 69.47 & 2.631 & 3.891 & 4.676 \\
MOJ_2 & 0.189 & 0.947 & 0.157 & 0.408 & nd & 0.324 & nd & 41.68 & 18.42 & 7.066 & 6.433 \\
CAB_2 & 0.201 & 0.891 & 0.13 & 0.309 & nd & 0.228 & nd & 5.632 & 5.334 & 17.93 & 1.997 \\
CAB_3 & 0.13 & 0.632 & 0.101 & 0.262 & nd & 0.223 & nd & 4.736 & 30.28 & 4.094 & 3.768 \\
Average & 0.1 & 0.7 & 0.1 & 0.3 & & 0.2 & & 30.4 & 14.1 & 8.2 & 4.2 \\
St deviation & 0.0 & 0.1 & 0.0 & 0.1 & & 0.0 & & 31.2 & 12.7 & 6.6 & 1.8 \\
Herrerías & & & & & & & & & & & \\
HERR_GUAD & 0.085 & 0.39 & nd & 0.115 & nd & nd & nd & 655.7 & 2.851 & 0.35 & 0.636 \\
HERR_22101 & 0.088 & 0.327 & 0.095 & 0.187 & nd & 0.147 & nd & 402.9 & 669.6 & 0.088 & 8.662 \\
Average & 0.1 & 0.3 & 0.0 & 0.1 & & 0.0 & & 529.3 & 336.2 & 0.2 & 4.6 \\
St deviation & 0.0 & 0.0 & 0.0 & 0.0 & & 0.1 & & 178.7 & 471.4 & 0.2 & 5.6 \\
\hline
\end{tabular}

$\mathrm{Nd}$ not detected

Samples from Cerro Minado have values between 18.627 and 18.855 for the ratio ${ }^{206} \mathrm{~Pb} /{ }^{204} \mathrm{~Pb}$, from 0.832 to 0.843 for ${ }^{207} \mathrm{~Pb} /{ }^{206} \mathrm{~Pb}$ and 2.061 to 2.088 for ${ }^{208} \mathrm{~Pb} /{ }^{206} \mathrm{~Pb}$, with the exception of two further radiogenic samples which are displaced to values of 19.015 and 19.643 for the ratio ${ }^{206} \mathrm{~Pb} /{ }^{204} \mathrm{~Pb}, 0.825$ and 0.801 for $207 \mathrm{~Pb} / 206 \mathrm{~Pb}$, and 2.036 and 1.972 for ${ }^{208} \mathrm{~Pb} /{ }^{206} \mathrm{~Pb}$. For the Cerro Minado case we also took a sample of the phyllites present as gangue in the deposit (sample CM12). This sample showed values significantly different from those from the copper ores (19.086 for ${ }^{206} \mathrm{~Pb} /{ }^{204} \mathrm{~Pb}, 0.823$ for ${ }^{207} \mathrm{~Pb} /{ }^{206} \mathrm{~Pb}, 2.069$ for ${ }^{208} \mathrm{~Pb} /{ }^{206} \mathrm{~Pb}, 15.720$ for ${ }^{207} \mathrm{~Pb} /{ }^{204} \mathrm{~Pb}$ and 39.492 for ${ }^{208} \mathrm{~Pb} /{ }^{204} \mathrm{~Pb}$ ) and has not been included in the graphs (Figs. 8, 9).

Finally, samples from Sierra Almagrera and Herrerías show very similar isotopic behaviour, with a practically complete overlap in the samples from the two areas in certain diagrams, something predictable given their similar hydrothermal genesis, although the samples from Herrerías show a greater dispersion towards non-overlapping zones. The range of these samples is from 18.738 to 18.771 for the ratio ${ }^{206} \mathrm{~Pb} /{ }^{204} \mathrm{~Pb}$, from 2.073 to $2.080 \mathrm{for}{ }^{208} \mathrm{~Pb} /{ }^{206} \mathrm{~Pb}$ and from 0.835 to 0.836 for 
${ }^{207} \mathrm{~Pb} /{ }^{206} \mathrm{~Pb}$. Two samples with values of 18.677 and $18.554,2.079$ and 2.084 for ${ }^{206} \mathrm{~Pb} /{ }^{204} \mathrm{~Pb}$, and 0.840 and 0.843 for ${ }^{208} \mathrm{~Pb} /{ }^{206} \mathrm{~Pb}$ and for ${ }^{207} \mathrm{~Pb} / 206 \mathrm{~Pb}$ have been considered outliers.

\section{Discussion}

Our new data show the existence of three isotopic fields (Figs. 8, 9), although some overlapping occurs. In order to define the isotopic ranges for Pinar de Bédar, Cerro Minado, Herrerías, Almagrera and Sierra Cabrera we have used in the first instance the results for the samples analysed by MC-ICP-MS as they have a lower analytical error. These data will be complemented with those already published and cited in the bibliography, obtained by TIMS, although it is necessary to take into account that the analytical error, especially for isotope ${ }^{204} \mathrm{~Pb}$, is considerably greater in the old TIMS results $( \pm 0.1 \%)$ than in the recent analysis using MC-ICPMS ( $\pm 0.01 \%)$ (Table 4).

Broadly, we have differentiated three isotopic fields: Firstly, an isotopic differentiation between Pinar de Bédar and Sierra Cabrera is not possible despite ore samples belonging to different complexes. This similarity in the isotopic signature of the two deposits is due to the fact that in both cases the copper deposit is associated with the same type of hydrothermal event, and where, in addition, the host rock lithology is similar (Permo-Triassic). A single field must be therefore defined for these samples, which can be discriminated from those of Cerro Minado and Herrerías/Sierra Almagrera.

Samples from Herrerías and Sierra Almagrera cannot be differentiated either due to their similar hydrothermal genesis and must also be considered a single isotopic field. The three samples of native silver from Herrerías, which we differentiate with arrows in the diagrams from the rest of the copper ores, appear rather displaced from the others in some diagrams, especially as regards the ${ }^{206} \mathrm{~Pb} /{ }^{204} \mathrm{~Pb}$ and ${ }^{207} \mathrm{~Pb} /{ }^{204} \mathrm{~Pb}$ ratios, which could be a consequence of the effect of mercury (present in high concentrations in the native silver from Herrerías) on the determination for isotope ${ }^{204} \mathrm{~Pb}$.

Cerro Minado is the most extended field with two outliers showing radiogenic values. We rule out the possibility that such extreme values are a consequence of a contamination of the isotopic ratios from the gangue in samples poor in copper, as the sample of the phyllites analysed showed 
values significantly different (especially for the isotope ${ }^{204} \mathrm{~Pb}$ ). Thus, they could be reflecting a tendency towards radiogenic signatures for this deposit, as another of the samples analysed by TIMS also shows these radiogenic values (19.165 for the ratio $\left.{ }^{206} \mathrm{~Pb} /{ }^{204} \mathrm{~Pb}\right)($ Table 4$)$.

If we add the old TIMS analyses we observe a partial overlap with the samples which we present here analysed via ICP-MS, although we must consider the greater analytical error which the said analyses display, especially in the diagrams which include the ${ }^{207} \mathrm{~Pb} /{ }^{204} \mathrm{~Pb}$ ratio (Figs. 10, 11).

We have plotted the isotopic fields of Cerro Minado, Pinar de Bédar/Sierra Cabrera and Almagrera/Herrerías as defined for samples analysed by TIMS (shadows) and current MC-ICPMS analyses (shadows with border lines); the resulting fields are predictably larger and the overlapping areas may be considered those of higher probability (Figs. 12, 13).

In terms of provenancing archaeological materials, distinctive elemental composition will contribute to discriminate between overlapping fields. Differences in chemical composition of these areas are illustrated in a principal components analysis (PCA) of the dataset (Fig. 14). The samples from Pinar de Bédar form a well-defined cluster differentiated from the rest. The samples from Sierra Cabrera are also well grouped while Cerro Minado and Herrerías are difficult to differentiate. A larger number of samples from Herrerías would perhaps help in its discrimination, but the site is now so obliterated after the open-cast mining activities of the 1990s, now covered up, that it is difficult to find any copper ore in situ nowadays. However, it is the combination of isotopic data and trace element analysis what would allow discriminating the source deposits of archaeological materials.

\section{Conclusions}

With this study we provide further data for a lead isotope and trace element characterisation of copper ores from southeastern Iberia for provenance studies. We thus fill a gap in pre-existing knowledge for an area that is very significant for the study of early metallurgy, with intensive archaeometallurgical studies but only disperse and unsystematic study of lead isotopes of ore deposits up to now. This study will facilitate interpretation of the origin of the copper ores in prehistoric and ancient metallurgy. 
Isotopic fields of Cerro Minado, Sierra Almagrera/Herrerías and Pinar de Bédar/Sierra Cabrera have been defined and can be discriminated.

Trace element compositions will also allow discrimination between mineralisations of similar genesis and therefore similar isotopic ratios (e.g. Pinar de Bédar and Sierra Cabrera), or between different overlapping isotopic fields (e.g. Cerro Minado and Sierra Almagrera/Herrerías).

Prehistoric mining works are usually difficult to identify due to modern exploitations. It is therefore indirect evidence of isotopic and trace elements matches between archaeometallurgical debris and copper mineralizations that will allow us to propose and test hypotheses about prehistoric copper procurement. The precise characterization of geological areas at a local level therefore becomes crucial. 
Journal of Iberian Geology, 2019, pp 1-24

Table 4 Results of lead isotope analysis by MC-ICP-MS. Old TIMS analyses collected from literature are also included

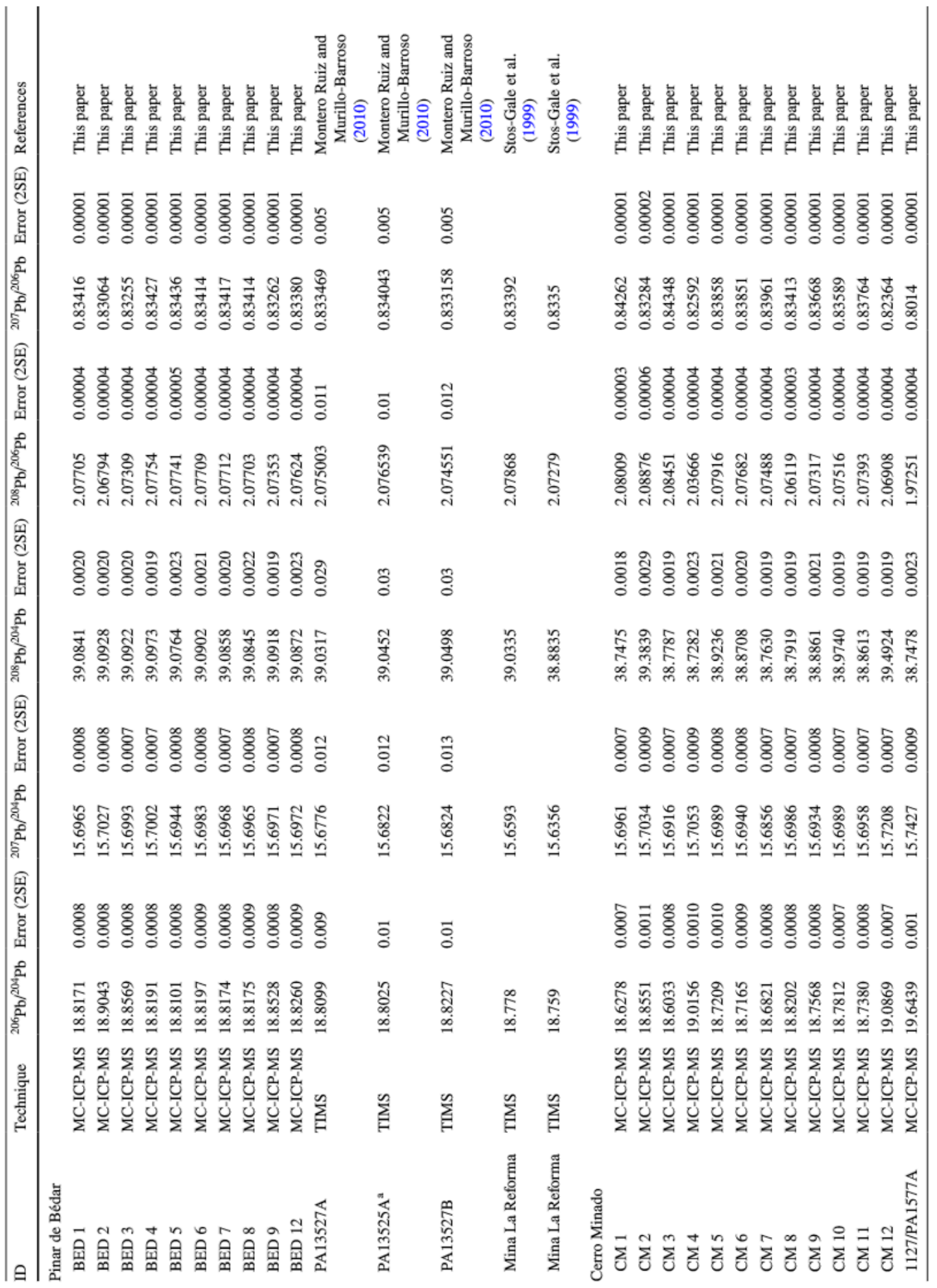


Journal of Iberian Geology, 2019, pp 1-24

Table 4 (continued)

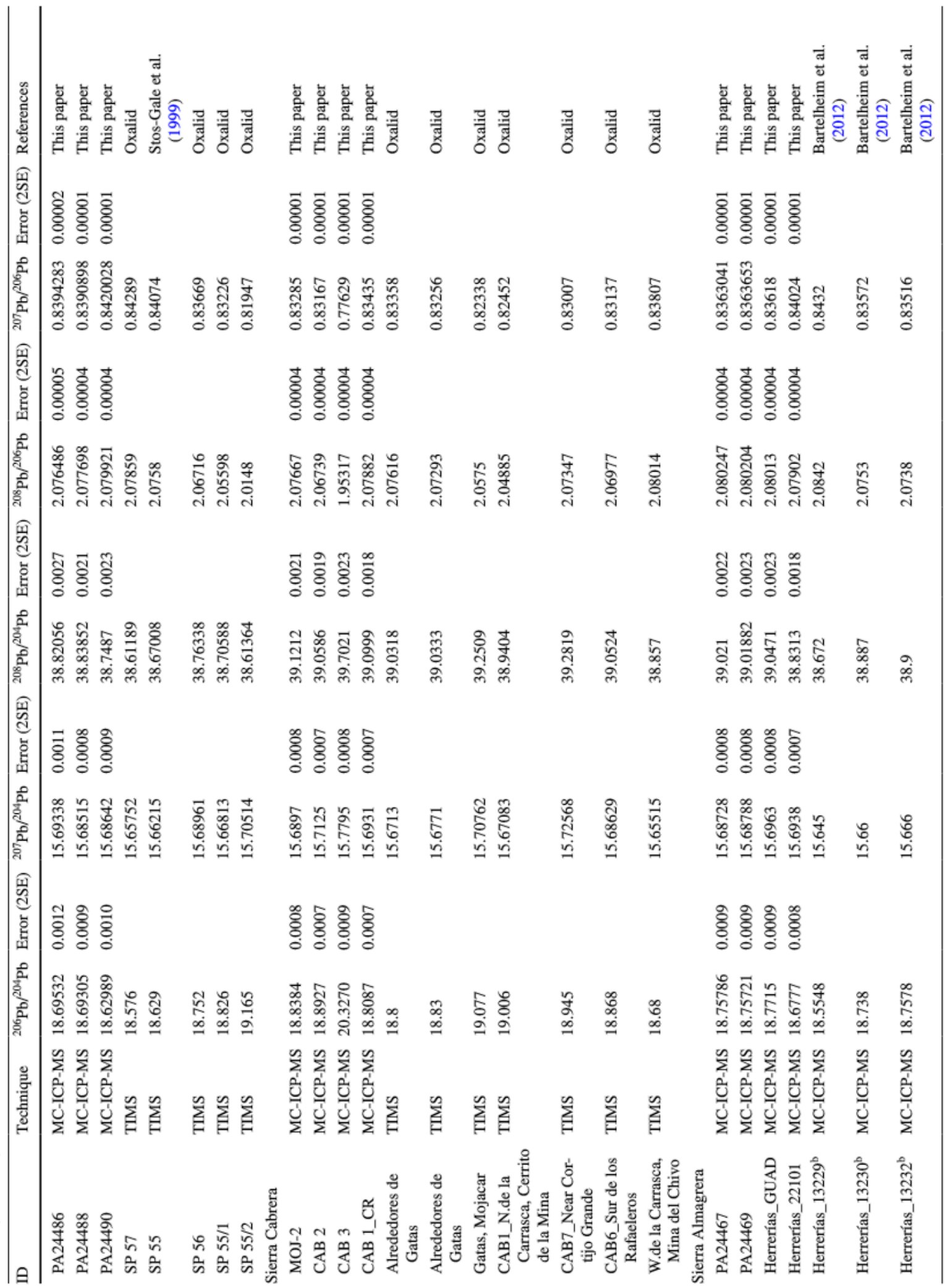


Journal of Iberian Geology, 2019, pp 1-24

Tale 4 (continued)

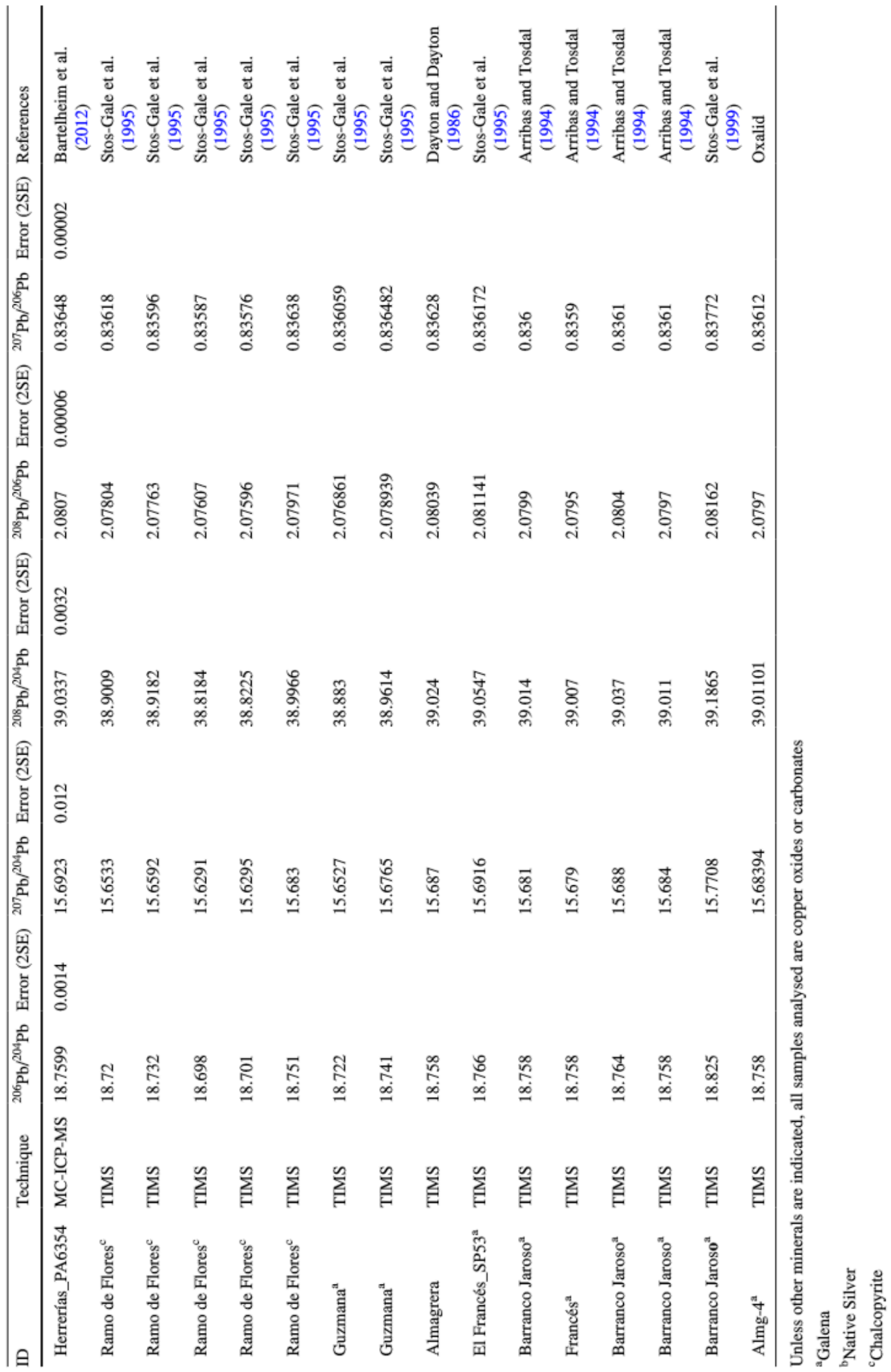



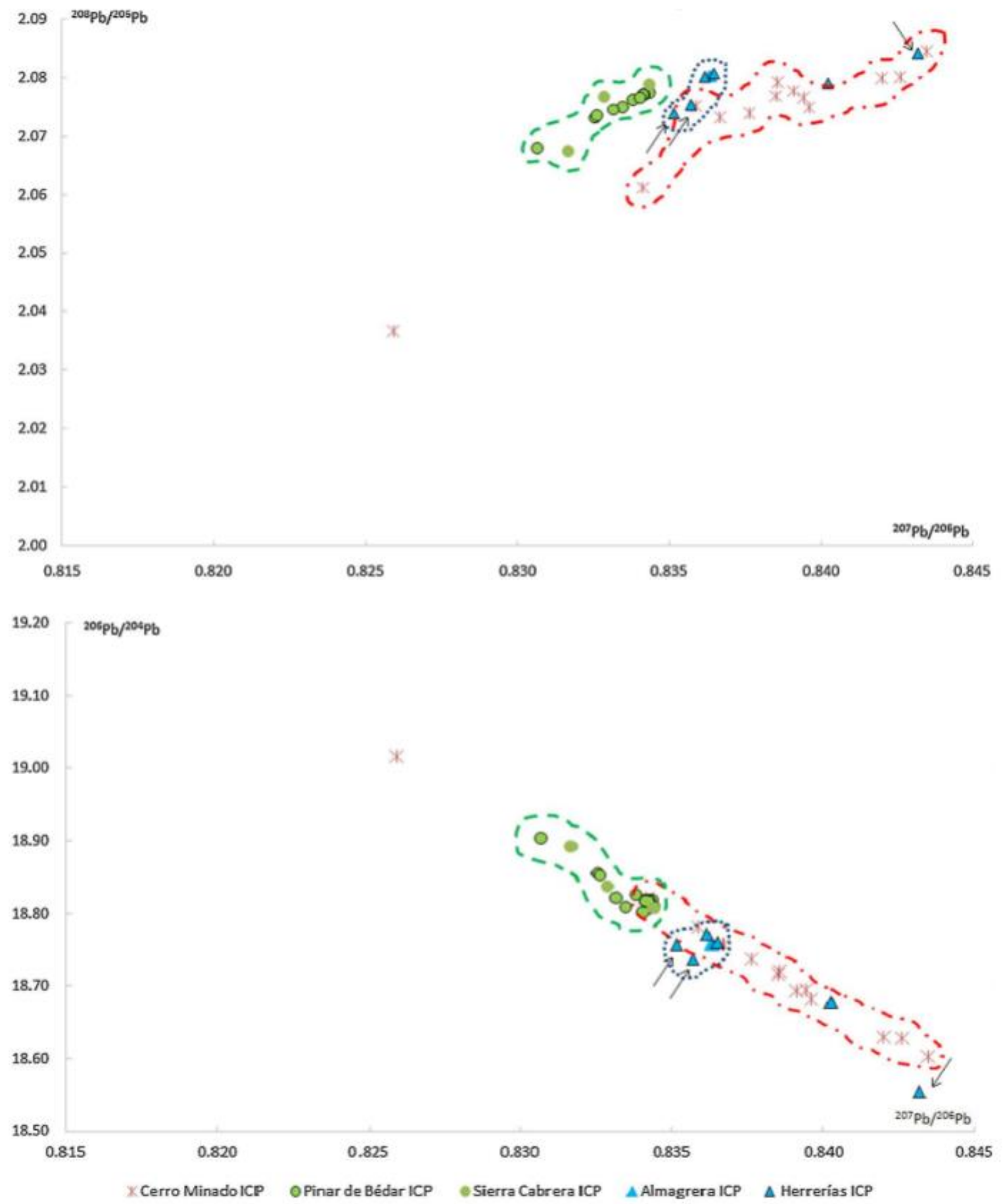

Fig. 8 Delimitation of isotopic fields of Cerro Minado, Pinar de Bédar/Sierra Cabrera and Almagrera/Herrerías in the isotopic ratios ${ }^{207} \mathrm{~Pb} /{ }^{206} \mathrm{~Pb}-{ }^{208} \mathrm{~Pb} /{ }^{206} \mathrm{~Pb}$ and ${ }^{207} \mathrm{~Pb} /{ }^{206} \mathrm{~Pb}-{ }^{206} \mathrm{~Pb} / 204 \mathrm{~Pb}$. Only samples analysed by MC-ICP-MS (Table 4) are included. Analytical errors smaller than symbols. Note that two samples from Herrerías and one from Cerro Minado are considered outliers and thus excluded from their isotopic fields. Samples 1127/PA1577A from Cerro Minado and CAB3 from Sierra Cabrera are not represented in the graph due to their low values in ${ }^{207} \mathrm{~Pb} / 206 \mathrm{~Pb}$ 


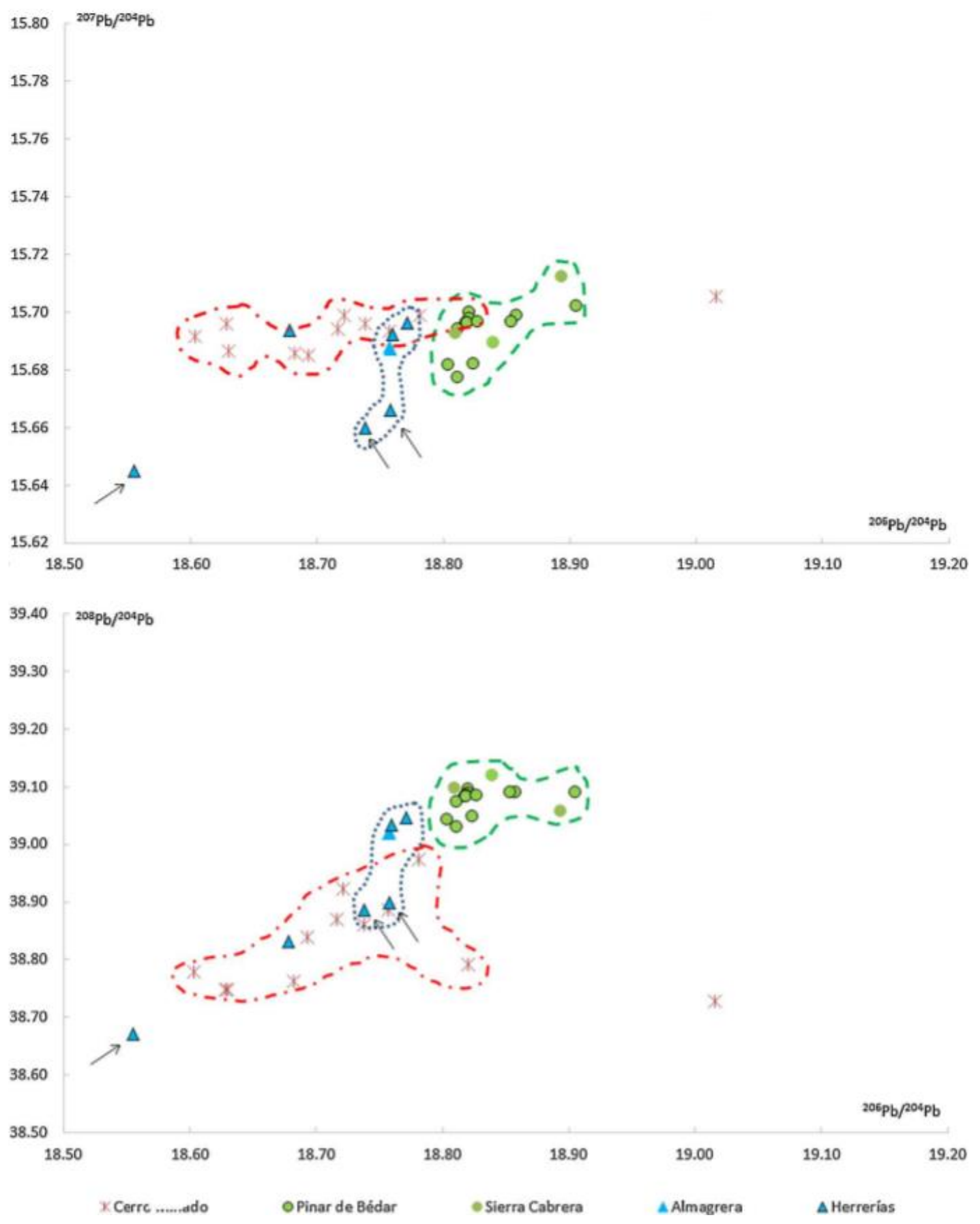

Fig. 9 Delimitation of isotopic fields of Cerro Minado, Pinar de Bédar/Sierra Cabrera and Almagrera/Herrerías in the isotopic ratios ${ }^{206} \mathrm{~Pb} / 204 \mathrm{~Pb}-{ }^{207} \mathrm{~Pb} / 204 \mathrm{~Pb}$ and ${ }^{206} \mathrm{~Pb} /{ }^{204} \mathrm{~Pb}{ }^{208} \mathrm{~Pb} / 204 \mathrm{~Pb}$. Only samples analysed by MC-ICP-MS (Table 4) are included. Analytical error smaller than symbols. Note that two samples from Herrerías and one from Cerro Minado are considered outliers and thus excluded from their isotopic fields. Samples 1127/PA1577A from Cerro Minado and CAB3 from Sierra Cabrera are not represented in the graph due to their high values in ${ }^{206} \mathrm{~Pb} / 204 \mathrm{~Pb}$ 
Journal of Iberian Geology, 2019, pp 1-24

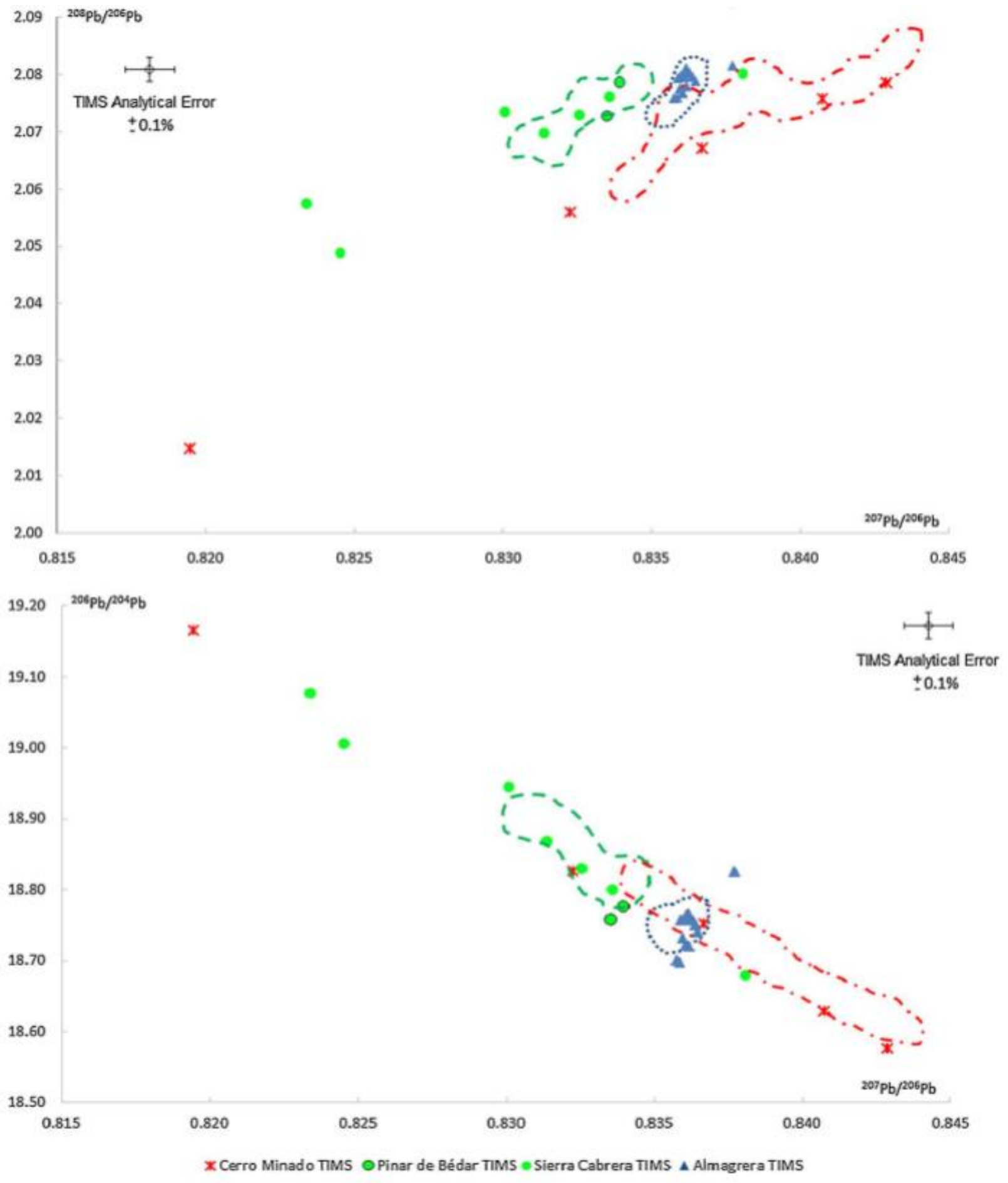

Fig. 10 Delimitation of isotopic fields of Cerro Minado, Pinar de Bédar/Sierra Cabrera and Almagrera/Herrerías in the isotopic ratios ${ }^{207} \mathrm{~Pb} /{ }^{206} \mathrm{~Pb}-{ }^{208} \mathrm{~Pb} /{ }^{206} \mathrm{~Pb}$ and ${ }^{207} \mathrm{~Pb} /{ }^{206} \mathrm{~Pb}-{ }^{206} \mathrm{~Pb} /{ }^{204} \mathrm{~Pb}$ based on samples analysed by MC-ICP-MS. Samples analysed by TIMS are included (Table 4) 
Journal of Iberian Geology, 2019, pp 1-24
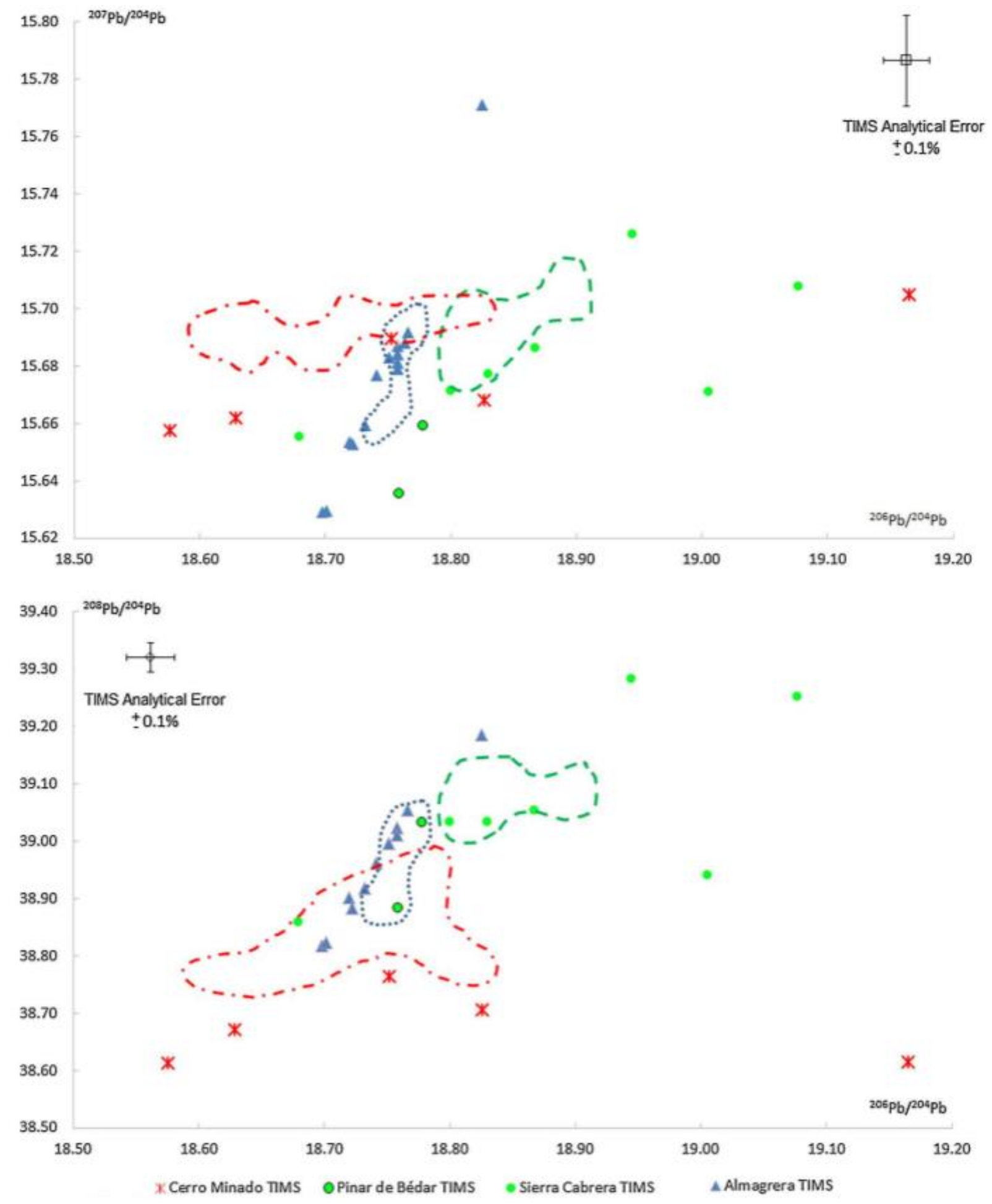

Fig. 11 Delimitation of isotopic fields of Cerro Minado, Pinar de Bédar/Sierra Cabrera and Almagrera/Herrerías in the isotopic ratios ${ }^{206} \mathrm{~Pb} / 204 \mathrm{~Pb}-207 \mathrm{~Pb} / 204 \mathrm{~Pb}$ and ${ }^{206} \mathrm{~Pb} / 204 \mathrm{~Pb}-{ }^{208} \mathrm{~Pb} /{ }^{204} \mathrm{~Pb}$ based on samples analysed by MC-ICP-MS. Samples analysed by TIMS are included (Table 4) 


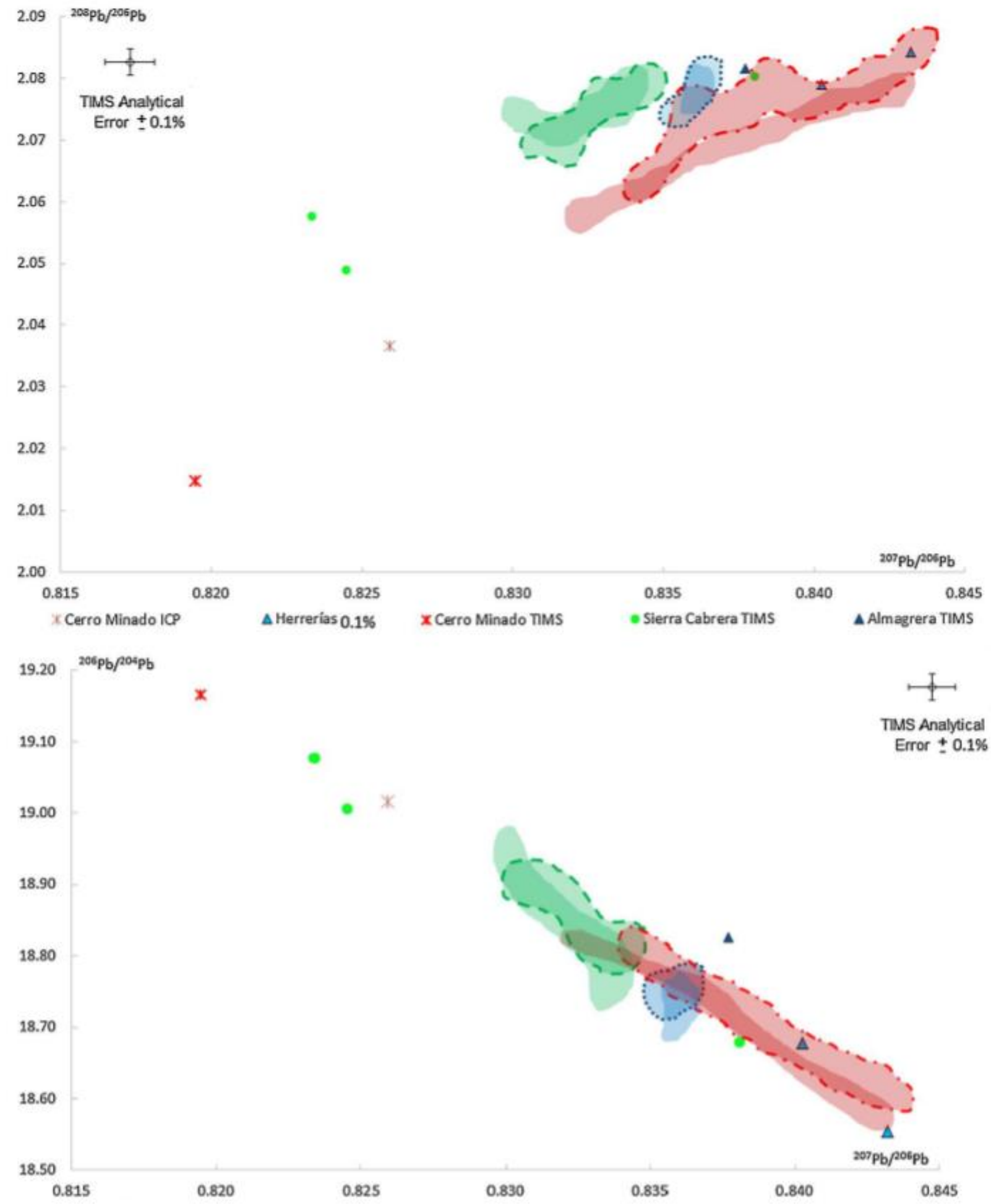

Fig. 12 Delimitation of isotopic fields of Cerro Minado, Pinar de Bédar/Sierra Cabrera and Almagrera/Herrerías in the isotopic ratios ${ }^{207} \mathrm{~Pb} / 206 \mathrm{~Pb}-208 \mathrm{~Pb} / 206 \mathrm{~Pb}$ and ${ }^{207} \mathrm{~Pb} / 206 \mathrm{~Pb}-206 \mathrm{~Pb} / 204 \mathrm{~Pb}$. Areas with border lines correspond to MC-ICP-MS analyses while areas without border lines are those for TIMS analyses. Both areas at $70 \%$ transparency to better identify overlapping 


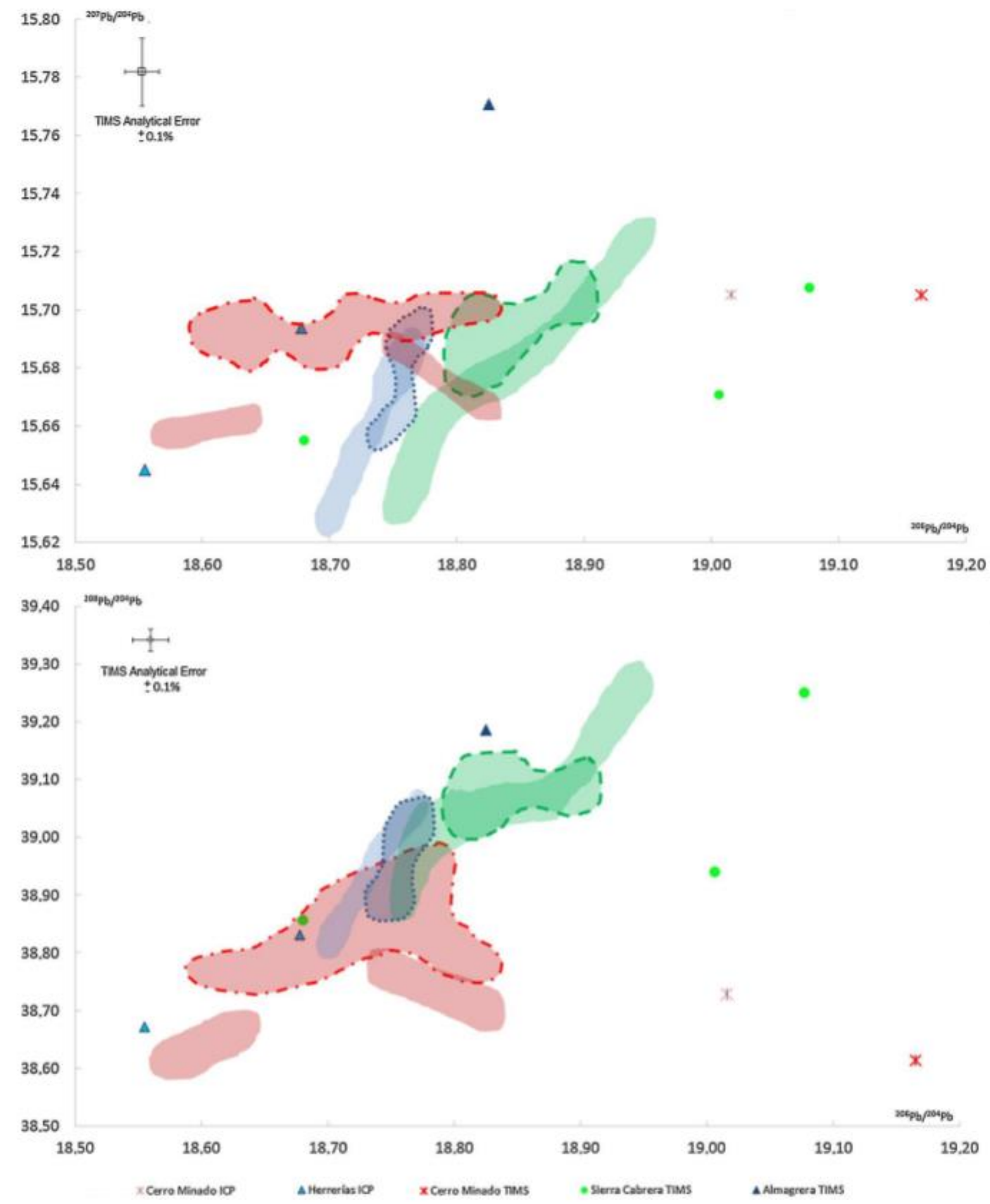

Fig. 13 Delimitation of isotopic fields of Cerro Minado, Pinar de Bédar/Sierra Cabrera and Almagrera/Herrerías in the isotopic ratios ${ }^{206} \mathrm{~Pb} /{ }^{204} \mathrm{~Pb}-207 \mathrm{~Pb} /{ }^{204} \mathrm{~Pb}$ and ${ }^{206} \mathrm{~Pb} /{ }^{204} \mathrm{~Pb}{ }^{208} \mathrm{~Pb} /{ }^{204} \mathrm{~Pb}$. Areas with border lines correspond to MC-ICP-MS analyses while areas without border lines are those for TIMS analyses. Both areas at $70 \%$ transparency to better identify overlapping 
Journal of Iberian Geology, 2019, pp 1-24

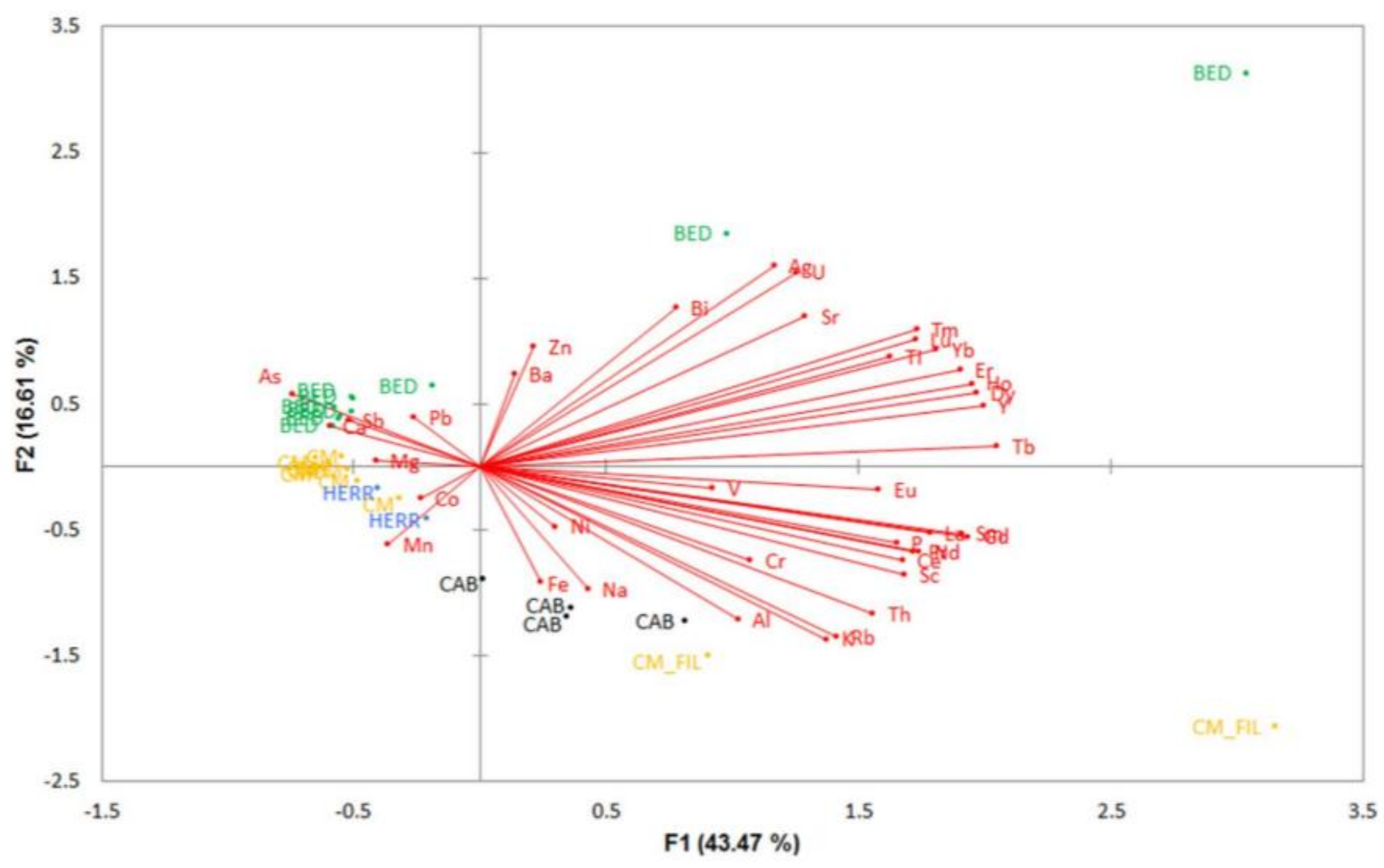

Fig. 14 Results of principal components analysis of trace elements composition

Acknowledgements This research was supported by a Marie Curie Intra European Fellowship within the 7th European Community Framework Programme ('Society, Metallurgy and Innovation: The Iberian Hypothesis'-SMITH project, PN623183); by the R\&D Projects HAR2017-82685-R, HAR2011-29068 and HAR-2016-78197-P funded by the Spanish Ministry of Economy and Competitiveness as well as by the Culture Office of the Government of Andalucía (Spain). We are grateful to Alexis Redondo for the design of the base map of Fig. 4. 
Journal of Iberian Geology, 2019, pp 1-24

\section{References}

Arribas, A., Jr., \& Tosdal, R. M. (1994). Isotopic composition of Pb in ore deposits in the Beltic Cordillera, Spain: Origin and relationship to other European deposit. Economic Geology, 89, 1074-1093.

Bartelheim, M., Contreras, F., Moreno, A., Murillo-Barroso, M., \& Pernicka, E. (2012). The silver of the South Iberian El Argar culture: A first look into production and distribution. Trabajos de Prehistoria, 69(2), 293-309.

Bertran-Oller, O., Buireu-Cabello, F., Febrer-Morlà, M., Enrique-Gisbert, P., \& Melgarejo, J. C. (2012). Mineralogía del Depósito de Cuesta Alta, Cerro Minado, Huércal-Overa, Almería. Macla, Revista de la Sociedad Española de Mineralogía, 16, 246-247.

Camalich Massieu, M. D., \& Martín Socas, D. (Eds.). (1999). El territorio almeriense desde los inicios de la producción hasta fines de la Antigüedad. Un modelo: La depresión de Vera y cuenca del río Almanzora. Sevilla: Conserjería de Cultura, Junta de Andalucía.

Carulla, N. (1987). Análisis geológico del territorio doméstico y del área de captación de Gatas. In R. Chapman, V. Lull, M. Picazo, \& M. E. Sanahuja (Eds.), Proyecto Gatas. Sociedad y economía en el sudeste de España c. 2500-800 a.n.e. 1 La prospección arqueoecológica British Archaeological Reports. International Series (Vol. 348, pp. 132-152). Oxford: Archaeopress.

Chernyshev, I. V., Chugaev, A. V., \& Shatagin, K. N. (2007). High-precision Pb isotope analysis by multicollector-ICPmass-spectrometry using 205TI/203TI Normalization: Optimization and calibration of the method for the studies of Pb isotope variations. Geochemistry International, 45(11), 1065-1076.

Dayton, J. E., \& Dayton, A. (1986). Uses and limitations of lead isotopes in archaeology. In J. S. Olin \& M. J. Blackman (Eds.), Proceedings of the 24th international archaeometry symposium (pp. 13-41). Washington: Smithsonian Institution Press.

Delgado Raak, S., Escanilla, N., \& Risch, R. (2014). Mazas ocultas. Rastros de minería prehistórica en el Cerro Minado de Huercal-Overa (Almería). Cuadernos de Prehistoria y Arqueología de la Universidad de Granada, 24, 13-44.

Delibes de Castro, G., Fernández-Miranda, M., Fernández-Posse, M. D., Martín, C., Montero Ruiz, I., \& RoviraLlorens, S. (1991). Almizaraque (Almería, Spain). Archaeometallurgy during the Chalcolithic in the South-East of the Iberian Peninsula. In C. Éluère \& J. P. Mohen (Eds.), Découvertedu Métal (pp. 303-315). Paris: Picard.

Delibes de Castro, G., \& Montero Ruiz, I. (Coords.) (1999). Las primeras etapas metalúrgicas en la Península Ibérica. II: Estudios regionales. Madrid: Instituto Universitario Ortega y Gasset.Domergue, C. (1987). Catalogue des mines et des fonderies antiques de la Péninsule Ibérique. Madrid: Publications de la Casa de Velázquez.

Escanilla, N. (2016). Recursos minerales de cobre y su explotación prehistórica en el sudeste peninsular. El valle del Guadalentín. PhD Thesis. Universitat Autònoma de Barcelona.

Favreau, G., Eytier, C., Eytier, J. R., \& Escanilla, N. (2013). Les mines de Cerro Minado, Huércal-Overa (Almería, Espagne). Le Cahier des Micromonteurs, 121, 3-122.

García de Madinabeitia, S., Sánchez Lorda, M. E., \& Gil Ibarguchi, J. I. (2008). Simultaneous determination of major to ultratrace elements in geological samples by fusion-dissolution and inductively coupled plasma mass spectrometry techniques. Analytica Chimica Acta, 625(2), 117-130.

González Quintero, P., Mederos, A., Díaz, A., Bashore, C., Chamón, J., \& Moreno, M. (2018). El poblado fortificado metalúrgico del calcolítico medio y final de Puente de Santa Bárbara (Huércal-Overa, Almería). Zephyrus, 81, 71-91. 
Journal of Iberian Geology, 2019, pp 1-24

IGME (Instituto Geológico Minero de España). (1975). Memoria del Mapa Geológico de España E1:50000 Vera. Madrid: Ministerio de Industria y Energía.

IGME (Instituto Geológico Minero de España). (1980). Memoria del Mapa Geológico de España E1:50000 HuércalOvera. Madrid: Ministerio de Industria y Energía.

IGME (Instituto Geológico Minero de España). (1983). Memoria del Mapa Geológico de España E1:50000 Carboneras. Madrid: Ministerio de Industria y Energía.

IGME (Instituto Geológico Minero de España). (2001). Mapa Geológico de España E1:1.000.000. Madrid: Ministerio de Industria y Energía.

Junghans, S., Sangmeister, E., \& Schröder, M. (1960). Metallanalysen Kupferzeitlicher und Frühbronzezeitlicher Bodenfunde aus Europas. Studien zu den Anfängen der Metallurgie (Vol. 1). Berlin: Mann.

Junghans, S., Sangmeister, E., \& Schröder, M. (1968). Kupfer und Bronze in der Frühen Metallzeit Europas. Katalog der Analysen Nr 985-10040. Studien zu den Anfängen der Metallurgie (Vol. 2, 3). Berlin: Mann.

Junghans, S., Sangmeister, E., \& Schröder, M. (1974). Kupfer und Bronze in der Frühen Metallzeit Europas. Katalog der Analysen Nr. 10041-22000. Studien zu den Anfängen der Metallurgie (Vol. 2, 3). Berlin: Mann.

López Gutiérrez, J., Martínez Frías, J., Lunar, R., \& López García, J. A. (1993). El Rombohorst mineralizado de las Herrerias: Un caso de « doming » e hidrotermalismo submarino mioceno en el SE Ibérico. Estudios Geológicos, 49, 13-19.

Martínez Frías, J. (1991). Sulphide and sulphosalt mineralogy and paragenesis from the Sierra Almagrera veins (SE Spain). Estudios Geológicos, 47, 271-279.

Martínez Frías, J. (1992). Yacimientos de plata Características Gen-erales y Metalogenia. In J. García Guinea \& J. Martínez Frías (Eds.), Recursos Minerales de España (pp. 893-920). Madrid: Consejo Superior de Investigaciones Científicas.

Martínez Frías, J., García Guinea, J., López Ruiz, J., López García, J. A., \& Benito García, R. (1989). Las mineralizaciones epitermales de Sierra Almagrera y de la Cuenca de Herrerías, Cordill-eras Bética. Boletín de la Sociedad Española de Mineralogía, 12, 261-271.

Miller J. N., \& Miller J. C. (2010). Statistics and chemometrics for anaytical chemistry. Essex: Pearson Education Limited, Prentice-Hall.

Montero Ruiz, I. (1994). El origen de la metalurgia en el sud-este de la Península lbérica. Almería: Instituto de Estudios Almerienses.

Montero Ruiz, I., \& Murillo-Barroso, M. (2010). La producción metalúrgica en las sociedades argáricas y sus implicaciones sociales: Una propuesta de investigación. Menga, Revista de Prehistoria de Andalucía, 1, 37-52.

Murillo-Barroso, M., Montero Ruiz, I., \& Bartelheim, M. (2014). Native silver resources in Iberia. In H. Harald Meller, R. Risch, \& E. Pernicka (Eds.), Metals of power. Early gold and silver (pp. 257-267). Halle: Tagungen des Landesmuseums für Vorgeschichte. 
Journal of Iberian Geology, 2019, pp 1-24

Murillo-Barroso, M., Martinón-Torres, M., Camalich Massieu, M. D., Martín Socas, D., \& Molina González, F. (2017).

Early metallurgy in SE Iberia. The workshop of Las Pilas (Mojácar, Almería, Spain). Archaeological and Anthropological Sciences, 9(7), 1539-1569. https ://doi.org/10.1007/s1252 0-016-0451-8.

Nobel, F. A., Andriessen, P. A. M., Hebeda, E. H., Priem, H. N. A., \& Rondell, H. E. (1981). Isotopic dating of the postalpine neogene volcanism in the Betic Cordilleras, Southern Spain. Geologie en Mijnbouw, 60, $209-214$.

Obón, A. (2017). Los inicios de la metalurgia del cobre en el Suroeste europeo. Aproximación experimental a la metalurgia de Almizaraque (Almería). PhD Thesis. Universidad de Zaragoza.

OXALID. The Oxford Archaeological Lead Isotope Database. http://oxali d.arch.ox.ac.uk/. Accessed 25 Feb 2019.

Pellico, R. (1852). Estracto de una memoria geológica sobre el distrito minero de Sierra Almagrera y Murcia. Madrid.

Pernicka, E. (2014). Provenance determination of archaeological metal objects. In B. W. Roberts \& C. P. Thornton (Eds.), Archaeometallurgy in global perspective: Methods and syntheses (pp. 239-268). New York: Springer.

Puga, E., Díaz De Federico, A., \& Nieto, J. M. (2002). Tectonostratigraphic subdivision and petrological characterization of the deepest complexes of the Betic zone: A review. Geodinamica Acta, 15, 23-43.

Revista Minera. (1850). Periódico Científico e Industrial. Tomo, I, 1-444.

Rovira, S., \& Montero, I. (2003). Natural tin-bronze alloy in Iberian Peninsula metallurgy: Potentiality and reality. In A. Giumlia-Mair \& F. Lo Schiavo (Eds.), The problem of early tin. Acts of the XIVth UISPP Congress Liege, 2-8 September 2001. Section 11 Bronze Age in Europe and the Mediterranean (pp. 15-22). British Archaeological Reports. International Series (Vol. 1199). Oxford: Archaeopress.

Ruiz Taboada, A., \& Montero Ruiz, I. (1999). The oldest metallurgy in western Europe. Antiquity, 73(282), 897-903.

Simon, O. J. (1963). Geological investigations in the Sierra de Almagro, SE Spain. PhD Thesis. University of Amsterdam.

Soler Jódar, J. A. (2014). Preparación Mecánica y fundición en las minas de plomo de Pinar de Bédar (Almería). Hastial, 4, 1-25.

Soler Jódar, J. A., \& Hansen, L. K. (2016). La Sociedad de explotación de las minas de hierro de Bedar. Axarquia, 16, 161-193.

Stos-Gale, Z. A., Gale, N. H., Houghton, J., \& Speakman, R. (1995). Lead Isotope data from the Isotrace Laboratory, Oxford: Archaeometry Data Base 1. Ores from the Western Mediterranean. Archaeometry, 37(2), 407-415.

Stos-Gale, S., Hunt Ortiz, M., \& Gale, N. (1999). Análisis elemental y de isótopos de plomo de objetos metálicos de los sondeos de Gatas. In P. Castro, R. Chapman, S. Gili, V. Lull, R. Micó, C. Rihuete, R. Risch, \& M. E. SanahujaYII (Eds.), Proyecto Gatas 2. La dinámica arqueoecológica de la ocupación prehistórica (pp. 347-361). Sevilla: Consejería de Cultura de la Junta de Andalucía. 